Año L. urtea

$125-2018$

Urtarrila-ekaina

Enero-junio

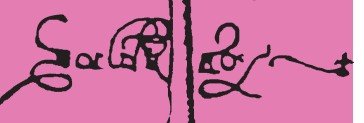

近

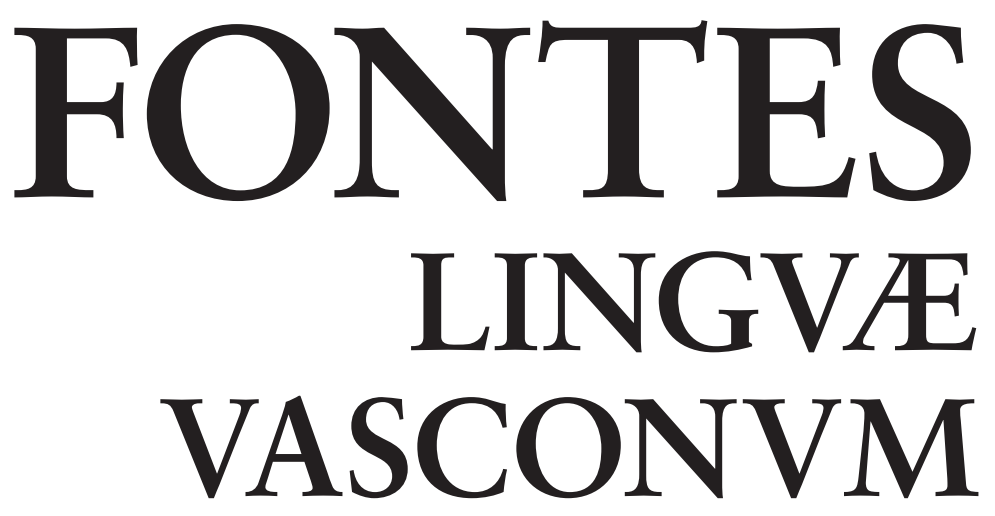

STVDIA ET DOCVMENTA

SEPARATA

Jean Barbier-en Piarres

XX. mendearen lehen erdiko

euskal eleberrigintzan

Ana M. Toledo

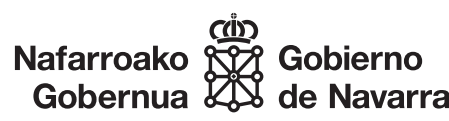

0000 


\section{Jean Barbier-en Piarres XX. mendearen lehen erdiko euskal eleberrigintzan}

Piarres, de Jean Barbier, en la narrativa en lengua vasca de la primera mitad del siglo XX

Jean Barbier's Piarres in the first half of the $20^{\text {th }}$ century basque narrative

Ana M. TOLEDO

Deustuko Unibertsitatea \& Euskaltzaindia

atoledo@deusto.es

\section{0}




\section{LABURPENA}

Jean Barbierren Piarres I (1926) eta Piarres II (1929) idazlanak aztertzen dira, XX. mendearen lehen erdiko euskal eleberrigintzan kokatuz. XIX. mendearen amaieratik, mende erdi luzean argitaratutako eleberri guztiak bat datoz erabilitako langaiak eratzeko moduan, baita adierazitako mundu-ikuskeran ere, baina Barbierrek badakar ezezagun zen osagairik: dela, aldi horretan gerrako ibilerez jardun zuen lehen eta azken eleberrigilea izatea, dela elkarren hizkuntza ulertzen ez zuten pertsonaiak borrokaren alderdi berdinean jartzea, dela herrikide eta kanpotarren artean muga berriak jartzea edo gizakia Jainkoak gobernatzen duela nabarmendu izana.

Gako hitzak: etnologia; etxea; Gerra Handia; inbaditzaileak; eleaniztasuna.

\section{RESUMEN}

Se analizan las obras Piarres I (1926) y Piarres II en el marco de la narrativa en lengua vasca generada en la primera mitad del siglo XX. Las novelas publicadas desde finales del siglo XIX hasta los comienzos de la segunda mitad coinciden en el modo de conformar los materiales utilizados y en la cosmovisión expuesta, pero Barbier, introduce también elementos que ningún otro había incorporado, sea la inclusión de sucesos de una guerra, o de soldados que combaten a las órdenes de mandos que desconocían su lengua, sea el establecimiento de nuevas fronteras entre compatriotas y foráneos, o la particularidad de subrayar que es Dios quien determina cada acto de la vida del ser humano.

Palabras clave: etnologia; casa; I Guerra Mundial; invasores; plurilingüismo.

\section{ABSTRACT}

Jean Barbier's Piarres I (1926) and Piarres II (1929) are analysed, placing them in the first half of the $20^{\text {th }}$ century narrative. From the end of the $19^{\text {th }}$ century, all the novels published in more than half a century coincide with the way of forming used materials and in the indicated way of viewing the world, but Barbier brings things that were unknown, for example, that he was the first and the last novelist who wrote about war those days, that he put in the same side of the fight characters that did not speak the same language, establishing to the nation and abroad new borders or underlining that the humans are ruled by God.

Keywords: ethnology; home; World War I; invaders; multilingual. 
1. Forma ETA LANGAI EZAGUNAK: NAABARDURAK. 2. GERRA LANGAIEN OSAGAI. 3. ETNOLOGIA ETA KRONIKA ETXEA GORDE ALDARRIKATZEKO. 4. ERREALITATE LINGUISTIKOAREN ISLAPENA. ELEBAKARRAK ETXE ELEANITZEAN. 5. JAINKOAREN NAHIAK GOBERNATUTAKO ETXEA. 6. ONDORIO GISA. 7. ERREFERENTZIAK.

Euskal literaturari buruzko historiek eta kritikek eleberriaren sailean kokatu izan duten Jean Barbierren Piarres I (1926) eta Piarres II (1929) liburukietan, beste osagai batzuekin batera, Gerra Handiaren (1914-1918) berri ematen da.

Malguetan malguena den eleberria generoak ez du eragozpenik izan elkarren artean antz handirik ez zeukaten kontakizunak barneratzeko. Horregatik, ez da harrigarri, azkenean, «genero mugagabe» legez «mugatzera» iritsi izana (Robert, 1973).

Genero mugagabe honetara bildu da Barbierren idazlana. Zinez, egun generoaren auzia planteatzeak ez du zentzurik, ez bakarrik prezeptiben garaia aspaldi amaitu zelako, baita literatur generoen arteko mugak hausten dituen idazlana ohiko ere bihurtu delako. Generoa aipatu bada, Barbierrek sorkaria argitaratu eta laster, P. Lafitte-k luzatutako epaiarengatik izan da: «c'est un corpus d'ethnologie basque» (1933, 35 or.). Ez zuen arrazoi-faltarik Lafittek: baserri giroko ohiturak eta tradizioak agertzen ditu. Alabaina, besterik ere gehitzen du: Gerra Handiaren kronika edo deitu ahal izango litzatekeena.

Kronika egitea oso berea izan du eleberriak; eleberri errealistak, kasu, garaikide zuen gizartearen kronika jaso zuen. Hainbesteraino, non Balzac-ek, adibidez, bere egunetako gizarte frantsesaren idazkari lanetan ari zela irizten zion (Aguiar e Silva, 1975, 187 or.). Begien bistan zeukan gizartean atzematen zuena adierazten ari zen. Orduko egunkariek ere, gizarteko gorabeherak jakinaraziko zituzten, ez ordea, Balzac-en moduan. Batak, kazetariak eta, besteak, eleberrigileak, gizarte berbera aurrean bazuten ere, kronika euskarri idatzira eramateko tankerak desberdintzen zituen. Langaiak partekatzen zituzten, ez horrela, langaiok testuan egikaritzeko era eta, ondorioz, ezta hartzailearengan eragin nahi zituzten efektuak ere. 
Barbierren idazlanera etorrita, Gerra Handiaren kronikari heldu izana aitor dakiokeen arren, langintza hau ez zuen bideratu ez kazetariaren, ez historialariaren, ezta eleberrigilearen ikuspuntutik ere, gaineratuko nuke, kazetariaren, historialariaren nahiz eleberrigilearen berbaldien nolakotasunetik urruntzen delako. Kazetariari bere orainaldiko zerbaitez ari den berriak batzea, laburbiltzea, hierarkizatzea eta argitaratzea badagokio eta, historialariari, oroimenean gordetzea merezi duten iragandako gertaerak azaltzea, beste eginkizun batez arduratzen da eleberrigilea: kronika polisemikoa taxutzeaz. Bestela esan, eleberrigileari arrotzak zaizkio kazetariak eta historialariak ezagutarazitakoek premiazko lituzketen zenbait ezaugarri: berbaldi hauek, eleberrigilearenak ez bezala, zehaztasuna eta zorroztasuna dituzte oinarri. Mugatuak izatea ezinbesteko duten kazetari eta historialariaren jardunaren ondoan, zehaztugabea da eleberrigilearena.

Eleberrigileak landutako testuak «hutsuneak» ditu irakurleak irakurtzean «bete» ditzan. Bere gogara «hutsuneak» «betez» (Iser, 1989, 133-148 orr.) doan irakurlearen irakurketa bide bizitza hartzen duen testua da. Irakurri bitartean irekia eta mugagabea da, irakurlearen irakurketak «ixten» duen arte. Hartzaile bakoitzak bere gisara beregana dezakeen testua da (Meregalli, 1989). Hala gerta dadin testuak esanahi askotarikoa izatea derrigorrezko. Horregatik, adiera anitzekoa bihurtzen doan hizkera-moldeaz baliatzeagatik, hain zuzen, zehaztasuna eta zorroztasuna gune dutenetatik bereizten da. Kazetariaren edo historialariaren kronikari data, gertalekua, gertari horien egile eta abarren izendapenean doitasuna galdegiten bazaie, beste eskakizunen bat du eleberrigileak. Beraz, Barbier kronikagilea aztertzean, ez da behatuko gorde zuen zorroztasunmaila, alderdi askoko testua osatzera eginiko ekarria baino.

Ondorioak aurreratuz: kazetariaren eta historialaren berbaldiek nahitaezko duten zehaztasun eta zorroztasuna alde batera utzita, baina, aldi berean, adiera bakarrekoa den kontakizuna onduz, eleberritik ere aldentzen den idazlana gauzatzen du Barbierrek. «Hutsune»rik gabeko testua burutzera jo zuen. Irakurketetara zabalik legokeenaren ordez, nola jaso ezartzen duena. Mezu jakina helarazi nahi du: etxea gorde. «Etxea» euskal etxea da. Euskal etxe hori, etxeko bizilagunen, elizaren eta arbasoen egoitza den hilerriaren gain eraikitzen da. Piarres I eta IIko Piarres pertsonaia nagusiaz kontalariak dioenez,

Oihanaldean sortua, Oihanaldean biziko zen beraz eta Oihanaldean hilen, Jainkoak nahiko zuelarik. (...).

Oihanaldean bethi hola gelditzen, elizaren, etxearen eta hilherrien gainean bermatuko $\mathrm{da} a^{1}$.

1 Azterketarako edizio eskuragarriago batera jo da: Sanchez, R. (arg.), 1992, 148 or. Testu-aipamenetako letra etzanak ediziokoak dira. Aurrerantzean ere, irizpide berbera jarraituko da: edizioak letra moldeaz egin erabilerari estu-estu eutsi. 
Oihanalde izen berezidun landetxearekin irudikatzen du euskal etxeak izan beharko lukeena. Etxe horren segida ziurtatzen duen bizilagunak, etxeaz bestalde, eliza eta hilerria ditu harroin ${ }^{2}$. Horra hor oinordekoaren zimentarrien izaera.

Euskal etxe hau etxe handiago batean kokatzen da: Frantzia. Alemanak indarrez Frantziaz jabetzen direnean, ezinbesteko da menperatzera datozenei aurre egitea dauzkaten zutarriek bere horretan iraun dezaten.

Oihanalde da Barbierren kontakizuneko ardatza, Piarres Iekoa ez ezik (Apestéguy, 1926, 611 or.), baita IIkoa ere. Gerra piztean, etxea defendatzera joatea zegokiola uste zuen Piarresek eta bukatzean, Goañarekin ezkonduta,

\section{xutik berriz bazagoken Etxea!}

Jainkoak hola manaturik, bertze Piarres eta Goaña ttiki batzu ethorriko ziren, (...). Kattalin emagin xaharrak eremanen zituen bathaiatzera (...) eta, beren aldian, xutik atxikiko zuten hek ere Etxe hura bera... ${ }^{3}$

Eredu bat baldin badago eta ereduak iraganean, orainean eta etorkizunean berdin jarrai dezala nahi bada, prozesu baten berri ematea baztertzen da, egon dagoena ibili dabilenari aurka jartzen zaiolako. Piarresek lau urte luze igaro arren gerran, higitze fisikoa baino ez da: psikologikoki geldirik dago. Etxea atxikitzeak darama gerrara. Piarres gudu-zelaietara laguntzen duen kontalariak gertaera eta eszenatoki lazgarriak agertu izanagatik, «onen» eta «gaiztoen» arteko borroka da: etxea beretu duten alemanak bota nahian diharduten frantses agintari militar eta soldadu zintzoak, soldadu euskaldunak zintzoetan zintzoenak eta ausartenetan ausartenak direlarik.

Gatazka ezabatzeak, matazarik ez harilkatzeak, adiera bakarrekoa den testua mamitzeak... eleberritik urrunarazten du eta, gerraz egin kronikan, nahiz datak eta gertalekuak aipatu, zehaztasuna eta zorroztasuna berbaldia taxutzeko irizpide ez izateak, kazetaritzatik eta historiatik. Azkenean, etnologia eta Gerra Handiko pasadizoak elikagai, testu hibrido bat moldatzen du, asmo jakinarekin: etxe eredugarriaren zutabeak bistaratu eta, edozein zirkunstantzietan, baita gogorrenetan ere, gorde beharra azpimarratu.

XX. mendearen lehen erdiko euskal eleberrigintzan, bada jazoeren kontakizuna lehenesten duenik, baina ohituretara arreta bildutakoak gainditzen du. Edonola ere, bata zein bestea gailendu, eleberriok bat datoz kontatutako istorioak testuan egikaritzeko

2 Lehenago ere jakinarazita zeuzkan benetako euskaldunaren zutarri horiek, baita oraingoan isiltzen duen bat gehitua ere. Supazter sokoan (1924) idazlanari egin aitzinsolasean dioenez, «Eta zerk egiten du Eskualduna zinezko Eskualdun? Elizak, Etxeak, Hil-Herriak, Mintzairak. Horietan datza Eskualdun arima guzia». Valencia, E. (arg.), 1987, 38 or.

3 Azterketan erabilitako edizioa: Loidi, A. (arg.), 1996, 216 or. Ik. lehen liburukiari egin oharra. 
moduan. Langaiei forma emateko eran barik, langaietan beraietan daude aldeak. Forma ematean, ereduak erakustea dute xede. Ereduaren balore-sistemako funtsezko osagai da kristau-sinesmen sendoa.

Egia da kristau-sinesmenak apaizak diren egileengan eragiten duela hitz-jariorik handiena eta laikoetan urriena. Apaizen artean Barbierrena izan zen ugariena. Bestaldean, laikoak leudeke, hala nola, J. M. Etxeita ${ }^{4}$. Zernahi gisaz, ez dago eleberririk helburu moralizatzaileari ihes egiten dionik.

Barbierren idazlanok euskal eleberrigintza argitaratuak hasitako ildoan jarraitzen dute, dela baliatutako ekaietan, dela ekaiok testura eroateko lantegian. Bere ñabardurak erantsiz, haatik. Nabardura horien artean aipa daitezke, matazarik ahulena ehotzea, arlo erlijiosoari tokirik zabalena eskaintzea, guztiek landa giroa goretsia bazuten ere, goraipamen horri, ordura arte egotzi gabeko motiboren bat emendatzea, gerraeremuko ibileren kontalari bakarra izatea... Honela bada, bere berezitasunak ditu.

Dagoeneko etnologia hornigai izana bazuen ere euskal eleberrigintzak, bada nobedaderen bat erabilitako kontuetan: etnologiari gerraren kronika batu izana. Gerraren gorabeherei tartea irekitzeak euskal eleberrigintzak planteatu gabe zituen auziei heltzea edo, ordurako ezaguna zenen bat testuinguru oso desberdinean kokatzea ere ekarriko du. Hala, lehenbiziko aldiz aurkezten da komunitate politiko mailako lokarria hizkuntza-komunitatearenari nagusitzen. Batak bestearen hizkuntza ez jakiteagatik, elkar ulertzen ez zuten pertsonaiak ez ziren ezezagunak euskal eleberrigintzan, bai horratik, kokalekua: gudu-zelaiaren alderdi berdinean, etxe bera defendatzen ari ziren.

Besterik ere, batu zion etnologia iturri izana zuten eleberriek ondutakoari.

\section{FORMA ETA LANGAI EZAGUNAK: NABARDURAK}

Baserri edo arrantzale giroko ohitura eta bizimoduaz ziharduen eleberririk bazen euskal literaturan. D. Agirreren Kresalan (1906) eta Garoan (1912) atzeman daiteke etnologiaren esku hartzerik, gutxieneko mataza bat eraikitzeari uko egin barik, ordea. Hona matazaren moldea: pertsonaia nagusiei nahigaberen bat sortuko zaie, edo zehatzago, pertsonaia nagusiei nahigaberen bat sorraraziko diete; izan ere, pertsonaia nagusiok eredugarriak izaki, ez dute gabeziarik; bigarren mailako pertsonaia bakan batzuetan, aldiz, badira grina edo ahuleziaren bat dutenak eta ahuleziok pertsonaia eredugarriarengana iritsiko dira, nahiz eta hau inoiz ez ailegatu modu arazotsuan bizitzera eragin dioten nahigabea.

4 Ik. Josecho (1909) eta Jaioterri Maitia (1910). Sariak eta zigorrak banatuz portaerak arautzen ditu, baina pertsonaien sinesmen eta praktika erlijiosoen berririk jaso gabe. 
Barbier ereduzkoa ez dena ia deuseztera gerturatu izanagatik, matazaren bat bilbatzeari begira emankortasunen bat izan zezakeen baliabide hau, zein bestelakoak, baztertzen ditu eta, ondorioz, etnologia biluzgorririk geratzen da Piarres I eta IIn. Piarresek, pertsonaia nagusiak, ez du gatazkarik, ezta horrelakorik ekarriko dion bigarren mailako pertsonaiarik ere. Gerrak, etxetik, senditik eta gustuko zuen neskarengandik urrundu izanak noiz edo noiz oroimin apur bat pizten badio ere, garapenerako zeukan gaitasuna, jakinarazte hutsarekin bukatzen da. Gerra, berriz, besteek hasi dute eta bera gudu-zelaian dago etxea, sendia, neska, herria eta Frantzia babesteko. Gerizatu egin behar dituela diotsa bere balore-sistemak. Balore-sistemak agindutakoa betetzen ari da bataila-eremuan eta bertako bizipenek ez dute ukitzen gerraurreko balore-sistema eta nortasuna.

Gerra hotsak entzunaz bat Piarresen Oihanalde landetxeko atea jo zuen Agustin beratarraren gonbit buru berotzaileak -ihes egin eta mugaz bestaldeko beratarraren baserrian laneratu- horixe lortzen du; ez besterik: une batez kaskoa berotu. Erantzun irmoaren ostean, behin betikoz amaitzen da bat etortze faltak mataza harilkatzen laguntzeko zuen birtualtasuna. Mataza ehotzen joateko birtualtasunak saihestuz, Oihanaldeko bizilagunak eta, batez ere, bertako oinordeko den Piarres pertsonaia nagusia «nola dagoen», «nola bizi den» azaltzea jomuga, ez da baliatzen ordu arteko euskal eleberrigintzak etekintsu izana zuen bitartekoaz: «ahuleziaren» bat, grinaren bat du(t)en bigarren mailako pertsonaiaren bat $(\mathrm{zu}) \mathrm{k}$ itxuratu, pertsonaia nagusi eredugarriak bere «egoteko modua», «bizitzeko modua», balore-sistema erakuts zezan. Aitzinetiko eleberrigintzan ahula bazen mataza, are gehiago indargabetzen du Barbierrek Piarres I eta IIn. Mataza makaldu ahala etnologia sendotzen da: bazen etnologiarik iraganeko ohiturazko eleberrigintzan, mataza ñimiño batera bildua, haatik; orain, hori ere ez.

Bizi izandakoaren harira eginaz doazen pertsonaiak barik, egonean dauden egindako pertsonaiak, jada aurkeztuak zituen, nola ohiturez, hala beste edozein langaiz, hornitutako euskal eleberriak. Egia esan, bigarren mailako pertsonaia baten nahiek edo sentipenek sor dezakete aldaketaren bat, baina, sekula ere ez, adierazitako bilakaera baten emaitza legez. Bat-batean mamitua, mirariaren erresumatik gizatiarrenetik baino hurbilago dagoen aldaketa da: jazoeraren batek argi egin izanaren fruitu. San Pablo zalditik erori zenean bezala.

Pertsonaia nagusiei dagokienez, euskara, euskal ohitura eta fede katolikoari atxikimenduak ezaugarritzen ditu. Hiru oinarri horien gain eraikitako balore-sistemako euskarrietako bat denboraldi batez alde batera uzten duen pertsonaia nagusi bakarra dago: R. M. Azkueren Ardi galduako (1918) Medel Olazarreta. Dena den, protestante bihurtzean galdutakoa berraurkituko du. Barbierrek ere, gainontzeko eleberrigileen norabidea hartuko du, idazlanaren izenburura eramanaz nabarmentzen duen Piarres, lau urtez gerra bizileku izan eta gero, joan aurretik zituen bereizgarri berdinekin itzultzeak erakusten duenez. Gerrako bizipenek ez dute inolako eraginik Piarresen nortasunean.

Halere, nobedaderen batzuk aitortu behar zaizkio Barbierri. Horietako bat, ordu arte euskal eleberriak estu-estu zaindua zuen decorumetik aldentzea. Esaterako, Agirrek, 
decorumaren izenean, Tramana eta Brix pertsonaiek esandako hitz zatarrak isiltzen ditu Kresalan. Behin edo behin iragartzen du, hauen berriketarekin jarraitzea bertan behera lagatzen duela, hitzen zatarkeriaren maila areagotzen zihoalako. Barbierrek, ostera, ez du eragozpenik izan gerran tokitu eta, horko txikizio eta sarraskiez aritzeko. Erretorika klasikoak agindutako decorumaren arabera, pertsonaiaren portaerak «egokia» eta "behar bezalakoa» izatea nahitaezkoa du eta ikuslearen sentikortasuna mindu edo iraindu dezaketen errealitatearen alderdi arruntenak ezin irudika daitezke. Gehienbat, sexuari, indarkeriari edo heriotzari buruzko eszenak ezkutatzea eskatzen du. Jakina da tragedia klasiko grekoan heriotzak «hegalen artean» gertatu behar zutela, ezkutuan, hartzaileak ikus ez zitzan.

Barbierrek ez zuen saihestu frontea Piarres IIn eta erretorika klasikoak «behar bezalako»tzat onartuko ez zituzkeen eszenek agerrera egiten dute. Alderdi guztietatik oinaze-sortzaile izanik, gerra-eremua ez da ereduzko lekua: janaria falta ez denean, hondatutakoa edo janezina ematen dietelako ${ }^{5}$; aurreragokoa den zereginen batek hildakoak lurperatzea ere oztopa dezakeelako ${ }^{6}$; adiskideak eta ezagunak ez ezik, norberak ere arriskua noiznahi lagun duelako, zeinahi unetan zaurituta edo hilotz gera daitekeelako... Piarresen bizitoki berriko nondik norakoak jasotzeak, halabeharrez zekarkion Barbierri triskantzari eta giro suntsitzaileari tartea irekitzea. Piarres etsaia bota nahian zebilen bitartean honen jaioterrian, edo jaiotetxe zuen Oihanalden gelditutakoenen gauzak kontatzea zuen aukera bakarra. Senpereko eta Oihanaldeko albisteei jaramon eginaz segitu zuen, gerra alboratu gabe, ordea.

Ausarta izan zela ere gainera daiteke, euskal eleberrigileak gerra-egoeretatik ihes egitea hobetsi baitzuen, XX. mendearen lehen erdian zehar. Horren lekuko beste euskaldun batzuk pairaturiko gerrak, nola gerra karlistak, hala Gerra Zibila (1936-1939). Istorioa gerra egunetara daraman eleberririk ez da falta, nahiz gerra karlisten garaira gibelatzen den J. Eizagirreren Ekaitzpean (1948), edo Gerra Zibilaren sasoian kokatzen diren Mendi-Lautak izenpetutako Loretxo (1937) eta J. A. Irazustaren Bizia garratza da (1950). Alabaina, Ekaitzpeanen, gerrateko aztarnen bat baino ez; izan ere, Aritzondo baserrian babestu duten gudu-zelaian zauritutako gaztearen eta bertako alabaren arteko harremana du ardatz: kontaera ez da tokitzen bataila-eremuan, Aritzondon

5 «noizpeit azkenean agertu ziren erreximenduko karroak. Ogi zerbeit ekartzen zuten, haizkoraz hautsi behar baitzen, batere hartarik jatekotz... Haragi bat aldiz! Haragia ere zenez, ageri ez baitzuen gehiago. Dena usteldura! Zortzi egun hartako haragia, bero hek guziek mutziturik, kasik hezurreraino usteldua!

Bere zathia eskuraturik, haren jaterat Piarres abiatu zelarik, bihotzak huts egin zion! Firrindilaka arthiki zuen usteldura hura guzia, eta ogi-mokor bat ahoan zehatu beharrez hasi zen. Joanes Garaztarra, hura, ixilixila, bazterrera burua itzulirik, haragi izigarriari lothua zen...

Bainan eskarnio guti gosearekin. Zonbeit egunez oraino jatekorik ez zen deus kasik agertu, (...). Eta lau egunen buruan, berriz itzuli zen Piarres bere haragi usteldua arthiki zuen tokira. Eta, goxara, hantxet, bi begiak hetsirik jan zuen... lau egun lehenago bazterrerat botatu zuen izigarrikeria hura bera, har-meta bat baizik ez baitzen gehiago...» (II, 32-33 orr.).

6 «Hilabetheak eta hilabetheak han behar ginen egon, urriaren $12 \mathrm{ko}$, urtharrilaren ondarreko guduetan erori soldadoen kapota urdinak eta galtza gorriak beren barneko gorphutzez husten ari zirela, egun guziez gehiago, gure gathe eta alhanbren aintzinean...

(...). Heientzat ez zen izanen ez kurutzerik hobiaren gainean, ez eta ere... hobirik» (II, 76 or.). 
baizik, eta gerrateko gorabeheretara gabe, maitasun-istorio batera biltzen du arreta. Ildo beretik dator Loretxo. Yon pertsonaia gerrara joan eta, hemengo jokamoldeak kontakizunaren korapiloa askatzeko erabakigarri izanagatik, kontalariak hitzik ere ez, noiz eta, alde batekoek eta bestekoek jarraitutako portaeretan oinarrituko duenean beste auzi baten konponketa. Yonen alderdikoak Loretxoren gurasoenekoak baino zuzenago aritu direlako, hauek aurretik begi onez ikusten ez zuten ezkontza baimentzen dute: Yon eta beren alabaren artekoa.

Gerra aitzakia hutsa da maitasun kontuak bideratzeko; ez besterik. Irazustaren Bizia garratza dan ere, gerra-esparrutik at garatzen da kontakizuna. Gerra dela eta, Bordelen Colonbiara ateratzen den itsasontzira igo ziren bi pertsonaien istorioa kontatzen $\mathrm{du}$, gerrak erbesteratu dituen pertsonaien bizitza. Etenak eragindako efektuak ditu kontakizun eta ez gerrakoak.

Testuinguru honetan azpimarragarria da Barbierrek Piarres soldadua bide, Gerra Handiaren kronikari heldu izana, egotzi dakizkiokeen ahulezia guztiekin bada ere. Eta kronika horretan ez zuen saihestu erakusgai ikaragarriak testura ekartzea, dela, dagoeneko aipatu diren elikatze-moduaz, lurperatu gabeko hilotzen itxuraz ${ }^{7}$, dela bizitzaegoeraz $^{8}$ diharduten pasarte gordinak.

Ustekabeak barik, kausalitateak ezartzen du euskal eleberrigintzako istorioen gertalekua. Hiriko bizimodua erdeinagarritzat daukatenez, aipa dezaketen arren, ezin izan kontatutakoaren gune. Ahotan hartzen dutenean, xede jakina betetzen du: zabal kontatzen den baserri edo arrantzale giroari aurka jarriz, ereduzkotzat jotzen duten landaeremua oraindik gehiago nabarmentzeko bitarteko dute.

Hobesten eta zabaldu gura duten balore-sistema kolokan jar dezakeelako arbuiatzen dute hiria. Eredugarria dena bistaratzea jomuga dutenez, ezin pertsonaia nagusi kaletar batez baliatu, ezta kontatutakoa kalean tokitu ere. Soka berdinari eusten dio Barbierrek Oihanalde hautatzean Piarres pertsonaia nagusiarentzat eta hiritarrei buruzko aipamenak izen bereziz izendatzera iristen ez den zenbait pertsonaiaren jarrera eta asmo gaitzesgarrietara mugatzean.

7 «Toki ustel hartan, han hemenka, aspaldi-aspaldi han erori frantses soldado batzuen gorphutzek iduri zuten mihise zikin batzuen tartetik harrotzen ari zirela. Urtzen baizik ez ziren ari eta mikotzen, egun guziez gehiago. (...), eta Piarres, luzaz meta ilhuneri beha egonik, othoitz baten erraiten ari zen, han eroriak eta bethi ezin-ehortziak zauden lagunentzat» (II, 134 or.).

8 «Ai! Sommeko lohiak, hamaseieko negu borthitzean, izaiten ahal den toki ustelenean. Ai! gauazko guardia ezin-erranezkoak, itsaso bat bezala alderdi guzietarik heldu zen basa higuinaren erdian, zangoak ubeltzen eta hormatzen ari zitzaizkotela orenetik orenera!

Lohi higuina, hastiala, okaztagarria, haxoinetarik eta galtzeri goiti, gerruntzean, bulharretan barna, lephoraino igaiten zena, hotz-hotza eta ixil-ixila, alimaleko apho itsusi bat bezala! Ez zen, lohiarentzat, ez gazterik, ez zaharrik, ez aintzindaririk. Oro bardin lohi zikinaren aintzinean, herioaren aintzinean bezala; (...) bethi, zauri itsusiena baino itsusiagoa; hotza, horma puska bat bezala, erhotzeko ere baitzen azkenean!

Kanoi-peza batek luze-luzea etzanarazi zituen ondoan, altxatzen ziren, izigarriak egiazki, lohia zariotela, lohi eginak zangoetarik eta kaskoraino»(II, 129-130 orr.). 
Hegoko eleberrigintzarentzat bezala, baserriko biziera eredugarriaren aurrean, galbidea zekarren kaleak. Ohitura gaiztoak ikasteko ingurune aproposa zen. Ikusi besterik ez dago, nola prozesioko senpertarrak «Tantum ergo» kantatzen ari zirenean, "karrosa batean Baionatik edo Miarritzetik ethorririk, (...) huna sei zazpi gizon gazte, hasten direla kantuz hek ere eskarnioka eta hirriz, elgarri keinuka» (I, 134-135 orr.) zebiltzan. Hegoko eleberrigintzak atzeman gabeko gaitzik ere gehitu zion hiriari Barbierrek, gosetea ekiditeko ezgai den barrutia izatea, hain justu:

ezen, zorigaitz hiriari, lan-sari handiaren gose eta egarriz, bas-herritarrak oro, edo gehienak, hiri hartara jautsiko direlarik! Harenak egin du egun hartan; eta noizpeit beraz, goseta ez jitekotz, noizpeit, beharko du hiritarrak berak bere lehenagoko mendi-alhorrerat itzuli (I, 148 or.).

Ohitura txarrei, gosea pairatzeko arriskua emendatzen dio: behar primario bat asetzea eragoz dezakeen esparruarekin ere uztartzen du hiria. Ez Barbierren idazlanok bakarrik, gainera. Geroago, J. P. Iratchet-ek Antton (1946) kontakizunean lotura berbera egin zuen. Hiriaren lilurapean, Anttoni emana zion ezkontza-hitza hausten duen Marixanek, zigor latza jasanez bukatuko du: berarekin ezkondu nahi zuenari janaria eskatuz, hiriak miseria gorrira eraman duelako.

Mundu hiritarra mespretxatzeak eta landatarra goresteak batzen ditu Hego eta Iparreko eleberriak, mespretxu berria erantsiz honek. Iparrean, Barbierrek aurkeztutako hiria-gosetea harremana, haatik, Iratchetena baino sakonagoa da; zeren eta, lehenak hiritarrak mehatxatzen dituen zorigaitz bezala ez ezik, hauek etxaguntzara heda dezaketen kalte moduan dakusa. Hirian, gosea nozi dezaketen herritarrez bestalde, baserrien inbaditzaileak ere bizi dira, jauregi ederrak eraiki nahian etxeok erosi nahi dituztenak, Piarresen aitak Oihanalde saltzeko jasotzen duen eskaintzak frogatzen duenez (I, 69 or.). Hortaz, badira goseak harrapa ditzakeen hiritarrak, baina, baita etxaldeko bizibidea irauliz, berau ezaba dezaketenak ere. Hiriak heriotza dakar: gosetea itzurtzeko noizbait lehenagoko basetxera itzuli beharko du kaletarrak; landa eremuko etxea jauretxe bihurtzeko beretzen duenak, iraganean zuen ezinbesteko eginkizuna kentzen dio: bizimodua ateratzeko zeuzkaten lurrez desjabetzen ditu bertako bizilagunak.

Zeinahi egoeretatik uxatu gura du gosetea Barbierrek, orobat gerrak sorraraz dezakeenetik:

Betirisantz ez zen agertu behar behin ere Olhaso kasko hetan... (II, 53 or.).

Ipar eta Hegoko eleberrigintzak bat datoz ereduan. Euskara, fede katolikoa eta euskal ohiturak ditu harroin ereduzko balore-sistemak. Langai batzuk ala bestelakoak erabili, mataza sendoagoa ala ahulagoa osatu, balore-sistema horretako euskarri jakinen bat gehiago ala gutxiago nabarmendu, pertsonaia eredugarriek ezaugarri berberak dituzte. Baserri giroa du gotorleku balore-sistema horrek. Pertsonaia eredugarriak zimentarri horiek dituen bizimoldea erakusten eta goraipatzen daude testuan. 
Barbierrek Piarres I eta IIn adierazitako mundu-ikuskera oso errotuta dago euskal kontakizunean. J. Perez de Lazarragaren (ca. 1547-1605) artzain kontakizunaren salbuespenarekin, hizkuntzak eta, batik bat, kristau-sinesmenak erakarria zuten hitz lauaren barrutia mugak poliki-poliki zabaltzen hastean, arlo profanoagoan barneratu arren, kristau-fedeak funtsezko tokia betetzen segitu zuen.

Esate baterako, autua testu-tipo egokia zen zerbait irakasten jarraitzeko. Euskaraz moldatutako lehen elkarrizketan, Peru Abarkan [1802]', azaleratutako mundu-ikuskeraren luzapena bermatzen ari da Barbier, ordu arte beste belaunaldi batzuetakoek egin eta, geroago ere, egingo duten legez. Horrela, iraunkortasun handikoa ez ezik, XX. mendearen bigarren erdi arte lehiakiderik gabekoa izango da: euskal eleberrigintzak munduikuskera bakarra adieraziko du. Ipar-Hegoen artean erabateko adostasuna, Barbierren Piarres I eta IIren ondotik burututako Iratcheten Anttonek berresten duenez.

Ingurumari honetan, deigarri gertatzen da nola eredu hutsak diren pertsonaia nagusiak eratu dituzten zenbait egilek ez duten eragozpenik izan ezarritako ordenaren manuren bat hauts zezaten. Jada J. A. Mogelen Peru Abarkan ezusteko jazoeraren bat hautematen zen, Peru eredua Maisu Juan justiziari kontu ematetik libratzen zuela ikustean. Topagune izan zuten tabernan Maisu Juanek eragindako kalteen lekuko izana zen Peruk, salaketa baztertzeaz bestalde, justizia eske datorren txinelaren atxiloketaagindua ekiditen laguntzen du. Mogelek Peru ereduari justiziaz trufatzen lagatzen dio; Barbierrek Piarres ereduari, mugazainez.

Berez Piarres ez da mugazainekin norgehiagokan sartzen den lehen pertsonaia, Ganix, J. B. Daskonagerreren Les échos du Pas de Rolandeko (1868) pertsonaia nagusia aitzindu baitzitzaion. Halere, euskaratu ostean Atheka gaitzeko oihartzunak (1870) izenburupean argitaratutako eleberriko Ganix ez da Piarresen anaia bikia. Daskonagerrek kontrabandista ospetsu izandako pertsona historiko baten eginkariak ezagutaraztea zuen helburu, Barbierrek, aitzitik, euskaldun eredugarri batenak. Gainera, Ganixek ez bezala, ikasbide doktrinalez jositako testu bat zuen bizileku euskaldun eredugarriak. Ereduetan eredu den Barbierren pertsonaia nagusia indarrean dagoen legeari jaramonik egin barik ibiltzeak, elizkoietan elizkoiena den Piarres kontrabandoaren alde azaltzeak, benetan sortzen du harridura. Ez soilki horrek, baita Jaungoikoaren laugarren manamendua zintzo asko gordetzen duenak, hain justu, gai horretan eta, horretan baino ez, amaren esana aintzakotzat ez hartzeak ere. Gaxuxak, semea bezain ereduzko den amak, bere alderditik, ez dio eskatzen kontrabandoa uztea iruzurra delako, legea begiratzen ez duelako, baizik eta atxilotu dezaketelako. Atxiloketak sendiari ekarriko liokeen ahalkeaz da beldur Gaxuxa. Ordura arte agertutako arrazoiek semea ez dutela konbentzitu atzematean eta ez entzunarena egingo duela igartzean, goragoko auctoritas batera joko du amak, «jaun erretorak nola ez zaitu bada kontrabanda madarikatu hortarik oraino gibelatua?»(I, 29 or.). Piarresen erantzuna, berriz,

9 Nahiz eta 1881erarte ez argitaratu, garaiko euskaltzaleen artean ezaguna zen eskuz egindako kopiei esker. 
Jaun erretorak barkatzen dauku kontrabandan ibili garenean, bainan ez dauku erranen, ez dezaguke erran kontrabandan ibil gaitezen. (...). Bertzalde, gure etxe-lanetan nahiago gintuzke harek ere, zuk bezala, ama, zeren, askotan etxeko segida galtzen duen kontrabandixt batek baino gehiagok (I, 29 or.).

Atxiloketa eta honen ondorioak kezkatzen dute Gaxuxa; «segidak» oinordekoa, etxearen segidak. Biak ere, etxea, sendia dute gogoan. Hain kristau zuzena den Piarresek, bekatua dela aitortzen du eta, horrenbestez, erretorearen barkamen-beharra daukala, baina, nonbait, aitorpen bakoitzaren ostean erretoreak jar zekiokeen penitentzia betetzearekin aski zuen. Legearekin leial jokatzeko asmo izpirik ez du erakusten, behintzat. Horra hor, obeditzen eta osoki errespetatzen dituen bi autoritateetatik urrunarazten duen gauza bakarra. Zer gertatzen da? Kontrabandoa ere "ohiturazkoa» dela, eta isil-gordeka baino ez dela urraketa?

Kontrabandoa onartzeko Piarresek azaldutako zioak ere badu mamirik:

Eta gero, Eskual-Herrian ez zen lehenago kontrabandarik, zeren ez zen muga-harririk. Zertako eman dituzte muga horiek Dantxariako edo Irungo zubieri hurbil? Eskualduna ez othe da berez bere ibili behar Eskual-Herri guziko mendietan? Gure lehenagoko zuzenetarik, hori bederen ez othe ginuen begiratu behar, hori bederen ez othe zaukuten utzi behar hego-aldetik edo iphar-aldetik guri nausitu erresumek? (I, 29 or.).

Mugarririk egon behar ez lukeen arren, dago. Hortaz, debekatuta dago kontrabandoa. Mugarria soberan dagoela uste duen Piarresek eta, uste horretan oinarrituz kontrabandoa zuritzen duen pertsonaiak, ziurtasunak baino ez dituen pertsonaia tinkoak, gai soila du besteren iritzietara irekita. Kontu bakarra dauka goragoko autoritate batek argitzea eskertuko lukeena: Frantziari atxikimendua gorde, euskal mendi guztietako jabe euskalduna izanaz:

Ez naiz batere Frantses-Herritik zeiartu beharrez ari, ama, zeren maitexko dutan Frantses-Herri handia. Bainan, behin ere ez baitiot aiphatu, ongi jakin nahia nindake, jaun erretorak zer othe dion hortaz? Kastillara batre gabe, eskualdun mendi guzietako zuzenen jabe eskualduna! Hoi hoi loria, ama! (I, 29-30 orr.).

Kontrabandoan jarduteaz desenkusatzeko esanak esan Piarresek, etxea Oihanalde du, herria Senpere, Euskal Herria Ipar aldekoa eta Herri Handia Frantzia.

Laburbilduz, Mogelen Peru Abarkak adierazitako ikuskerari eusten dio Barbierrek, aurretiko eleberrigileen kokagunean finkatuz. Piarresek balore-sistema jakina zutarri, atsegin du bere bizimodua, nola pilotaz edo mus karta-jokoaz gozatzen, hala kontrabandoan edo elizak antolatutako elizkizun guztietan parte hartzen. Balore-sistema eta bizimoldea bistaratzen ari dela, gerrak atea joko du, nahiz eta eginbeharra garbi daukan Piarres ez asaldatu. Gerrak dirauen lau urteetan gutxitan itzuliko bada ere, dabiltzan lekuetara herriko albisteak heltzen zaizkie. Albisteok eta herriratzeko ematen dizkioten baimenak baliatzen dira senpertarrek gerraren nondik norakoei begira daudela jakinarazteaz gain, lehen liburukian jaso gabeko zenbait ohitura gehitzeko, dela 
soroetako harrak uxatzeko egiten duten zeremonia, dela senpertarrek bizitzako iraganbide desberdinetarako, heriotza, zein ezkontza-eskari eta ezteietarako, dauzkaten protokoloak. Lehen liburukiaren alor etnologikoa bigarrenarekin osatzen da. Gerrak ez dakar etenik ez horretan, ezta Piarresengan ere: lehen nola orain, alderdi zuzenean. Gerrak egoera gogaikarriak sortu izanagatik, ez ditu arazotsu bihurtzen: dagokion eginkizuna betetzen jarduteak sendotzen du. Lehenagoko bizieraren iraupena bermatzeak eskatutakoari erantzuten ari zaio. Garaipena eskuratzean lortuko du.

\section{GERRA LANGAIEN OSAGAI}

Kronikarik ez dago Piarres Iean, gutxienez, «Gerla! Gerla!» izenburua daraman XVI. kapitulu arte: lehen liburukiaren azkena. Bigarrenean ere, askorik ez dagoela ondoriozta daiteke, kontuan izanik Piarresek urteak igaro zituela Marne, Verdun, Somme, Champagna eta abarretan. «Hitz batez, berrogoi-ta-hamar bat orrialde ditu eskas Piarres liburu bigarrenak, gerlako zer guzien mirail izaiteko osoki» zioen J. Etcheparek argitaratu zen urtean, 1929an, Gure Herrian (Charritton, 1984, 362 or.), "gerla izigarri hartako ipizta eta iturburuak», «erresumen arteko hisiak» (361 or.) eta abar ez aztertu izana, eta «siska handiak egin izan ziren eskualdetako berriak laburzkiegi» (362 or.) adieraztea salatuz ${ }^{10}$.

Ez du arrazoi-faltarik Etcheparek; izan ere, pertsonaia nagusiaren gerrako gorabeherak segitzea erabakitzen duen une beretik gerraren kronika egiteko aukera aparta zeukan Barbierrek. Ildo honetara mugatzeak, Piarres Iean harilkatutakoarekin hausteak, babestu nahi zutena erakusten jarraitzea galarazten zion eta bestela jokatu zuen: gorde beharrezkotzat daukatena ez da desagertzen eta toki narratiboa betez doa, borrokan arreta zehatzagoa jartzeari eskaini zekiokeen tartea xahutuz.

Gerraren iturburuak, bataila-eremuak eta bertako gertaerak xehe-xehe araka zitzakeen, baita jazoera horiek gizabanakoarengan sorraraz zitzaketen sentimenduak eta besterik ere, baina beste langai batzuk eranstea lehenetsiz, aurreneko liburukiarekiko harremana estutzen du.

Gerra Handia amaitu zen urtean argitaratu zen Azkueren Ardi galdua zela eta, honela mintzatu zen P. Lhande:

Aussi ne faut-il chercher dans ce roman ni intrigue tont soit peu complexe, ni analyses sentimentales. Peut-être, même, l'auteur eut-il réussi à faire une oeuvre plus populaire s'il n'eût pas abordé un sujet qui demande précisément une étude profonde des sentiments les plus cachés; je veux dire, la conversion d'une âme (1919, 194-195 orr.).

10 Gure Herrian «Eritzi eta kitzika» sailean ez ezik, beste nonbait ere jardun zuen Etcheparek Piarres IIri buruz: urte berean aldizkari horretan bertan emanaldika kaleratzen hasi zen «Beribilez»en. Oraingoan, balioespen orokorragoak eginaz, zeinahi idazlek bere idazlanarekin lortu nahi lukeen onurarik estimatuena iragartzen dio, irautea, hain zuzen: «Badirauke luzaz gutartean Barbier kartsuaren orhoitzapenak». Kerejeta, M. J. (arg.), 1987, 178 or. 
Antza denez, garaiko gaitza da. Lhandek Ardi galduan atzemandakoa Piarres I eta IIra heda daiteke: esan bezala, ez dago, ez intriga konplexurik, ez sinplerik, ezta pertsonaian sakontzerik ere. Azkuek pertsonaia gogoetetan barneratzeko moduko gaia erabili bazuen -fede katolikoa galdua zuen Medel Olazarretak fede hori berreskuratzea- baita Barbierrek ere, gerrarako deiak gudu-zelaiz gudu-zelai ibiltzea eskatuko dioenean Piarresi. Haatik, batean zein bestean, gatazka deuseztatzen da, pertsonaiaren bat-bateko konbertitzeari esker lehenbizikoan, egitekoa derrigortzat jotzetik ernetako eroapen itzela bide, bigarrenean. Gerra-toki desberdinetako pasadizo batzuen berri emateko eta, batez ere, egoeraren eskakizunen gaineko uste irmoak zenbaterainoko kemena duen azaltzeko bitarteko hutsa du Piarres Barbierrek.

Gakoa, azkenean, eratu duen pertsonaia nagusian dago. Piarres pertsonaia, hain da pertsonaia ziurra, hain da erantzunak dituen pertsonaia eta zalantza zer den ez dakiena, hain da esanekoa (kontrabandoaren kontuan izan ezik) eta errebeldia ukiturik gabea, gerrako basakeria eta gizagabetasuna ere naturaltasunez eta barrenak astintzen ez zaizkiola -barrenak irakin gabe- pairatzeko gauza dela.

Gerra Handiak konfrontazioaren erdi-erdian kokatzen baditu ere, ez Piarresek, ezta bere inguruan dabiltzan soldadu euskaldunek ere, bizi dute modu gatazkatsuan arazoa, euskarri duten balore-sistemari esker. Balore-sistemaren oinarri sendoak, bizipenen eragin oro baliogabetzen du: daukan indarrak egokitu zaizkien baldintza zailak menperatzeko gaitasuna du. Balore-sistemaren aginduetara daude eta gerta ala gerta ez dute auzitan jarriko, ez gerrak kausatutako biziera anker eta arriskutsuak, ez beren ohiko hizkuntza agintarien ahotsean ez entzuteak, ezta beste ezertxok ere. Gizatasuna kendu zaien pertsonaiak dira: hala jokatzen dute behintzat. Aitaren etxea eraso dutenei aurre egitera joan dira eta, nahiz eginbide horretan, edo bizitzako edozeinetan, Jainkoaren nahia betetzen dela sinesten dute, ezbairik gabe. Jainkoaren gogoak gobernatzen dituela dioten pertsonaiak moldatzen ditu Barbierrek. Horregatik, hain zuzen, ingurune gordina bizileku duten soldadu euskaldunak, esku artean duten lantegian akitu arte saiatuz, Jainkoaren borondateari makurtzen zaizkio.

Bistakoa da Piarresek gerran igarotako lau urteak berrogeita hamar orrialdetara biltzeko nahitaezko duela laburpena eta elipsia erabiltzea. Kontatzen dituen gorabeherak laburpena eta, batik bat, elipsia baliatuz taxututako zoruan altxatzen ditu. Behin batean gertaturikoa, beste batean jazotakoa... Hautatutako pasadizo hauetan maiz jotzen du denboraren ardatza zehaztera: eguna, ordua, iraupena: «Urtharrilaren ondarrean, 25, 26, eta 27an, fur-furian berriz ere athera zitzaioten etsaia» (II, 73 or.); «Hogoita hiruan, goizeko bederatzi orenetan, manu bat heldu zaiote orori: Baionnettes au $\mathrm{Ca}$ non» (II, 15 or.) kainoi alemanak gainean zituztelako; «Eta maiatzaren 4ean beraz, arratsaldeko lau oren beretan, (...) gehiago oraino errabiatu ziren gure kanoiak (...). Eta gero, bostak eta erdietan, (...).

Sei orenetan, luzeago oraino egin zen gure sua» (II, 141 or.).

Xehetasunok gudu-zelaian bizi izandako une erabakigarrietara ez ezik, uneok ailegatu aurretxora ere hedatzen ditu, hala nola Verduneko bataila-eremura abiatzean, datak 
pilatzen dituenean: «aphirilaren 21ean» (II, 112 or.), «maiatzaren 6an. Eta, hamabortz egunez gero» (II, 112 or.), «Hogoiean, (...) bazoazin orai Verdunerat, 21ean eta 22ean han» (II, 112 or.). Herioaren erresuma izango denez Verdun, ataritik bertatik hasten da iragartzen agertoki beldurgarrian sartzear daudela.

Alabaina, denbora-marken eransketa ez da atxikitzen egoera larria edo gain-gainean daukatela adierazteari. Ez da gerraz aritzeko gordetzen den baliabidea, ohiko bizimoduko pasarteetara ere zabaltzen baita. Esaterako, Oihanaldeko sendiak «Arratsaldean, bi orenak irian» (II, 106 or.) ikusi zuten erretorea etxera zetorkiela. Kontalariak ordu beteko solasaldia izan zutela gaineratu ostean, bisitariak adeitasunezko ikustaldiaz haratagokoa dakarrela jakinarazi eta, zereginari heltzera bideratuko dira.

Denbora-markak gerraren kronikan metatu izanagatik, ezin ondoriozta daiteke, ohikotasuna eta gerrak eragindakoa bereizteko bitarteko izan dituenik.

Gerra Handiaz ziharduenean historiara lerratzen zen aldetik, leku-denbora mailako argibideak gehitzea eskakizun ere bazituela esan daiteke, pertsonaia nagusiaren «erreximenduaren» ibilerak egiazkoak zirelako. Hala ere, ez zuen behar besteko zorroztasunarekin burutu historialari lana, ez bakarrik, Etcheparek ohartarazi bezala, motz geratu izanagatik, baita denbora-markak osatu gabe uzteagatik ere: hilabetea, eguna, ordua zehaztu zituen, urtea, ordea, bakanka baino ez, lau urtez luzatu zenean gatazka.

Inoiz laburpenera jo arren, «Eta, bizkitartean, aboztuaren 30etik eta buruilaren zazpigarren eguneraino, hola iraun zuten gure gizon dohakabeek» (II, 28 or.), elipsia nagusitzen da. Elipsiaren oparotasunaren gain eraikitzen den kronika da. Behin edo behin, elipsia esplizitua bada ere -«Egunak, asteak, hilabetheak ere gero joan behar ziren holaxet» (II, 46 or.)- ukaezinezko moduan inplizituak gailentzen dira, jauzika doalako kontagarritzat dituen gauzen artean: "Orhoitzeko egun hetarik batez, arratsalde erditan» (II, 22 or.) jazotakoa; «Buruilaren 8a zen, unhadurak oro kolpez ahantzi behar ziren eguna» (II, 29 or.), pauso bakar bat atzera egiterik ez zeukatenekoa; soldaduei lehen eskutitza ailegatu zitzaien egunekoa, Piarresi dagokionez, Senperen abuztuaren 22an (urterik gabe) datatutako arreba Mariek igorritakoa; "Arratsalde batez» Piarresek arbolan zeuden bi aleman hil zituenekoa (II, 44-45 orr.); urriaren 4an kapilauak emandako meza (II, 62-63 orr.); euskaldunen meza (II, 69-70 orr.)...

Barbierrek ez zuen helburu gerraren kronikagile izatea, baizik eta zein bizimolde eta balore-sistemaren izenean aurre egin zioten etsaiari azaltzea. Lau urteko nondik norakoen berriak aukeratutako pasadizo batzuetara mugatu dituenak, ez du aurrezten berbaldirik Piarres «permisioneren» batekin Senpereratzen denean. Nahiz eta egun gutxi batzuen salbuespenarekin, gerran iragandako aldia izan, etxeratzeko baimena eskuratzen duenean, hemengo zereginak gerratekoak baino xehetasun gehiagoz hornitzen ditu, dela kantatzen dituen bertsoak testuan jasotzeak, dela erretoreak har kaltegarriak soroetarik uxatzeko erabilitako erritua txertatzeak (II, 107 or.) edo, herriratuz gero, «Biharamunean, bortz orenetako elizarat jo zuen jaun erretorari kofesatzeko eta haren solas bihotz-altxagarrien hartzeko» (II, 103 or.) eta "Arratsaldean gero, hilen bezperak akabatzearekin, Senpere guzia bi lerrotan bazoan hil-herrietara, bethiko proesionea 
egin beharrez» (II, 104 or.), jadanik ondo jakina zen Piarresen elizkoitasunaren ezaugarriarekin temati segitzeak, erakusten dutenez.

Gaxuxa gaixotzean ere, Piarresekin batera Senpereratzen da kontalaria. Sendagilea deitzetik «oren bat» (II, 150 or.) itxaron zutela zertzelada emendatuko du. «Etxek-andre Baten Hiltzea» izenburupean kapitulu oso bat hartuko du Gaxuxaren gaixotzeak, heriotzak eta ondorengo hileta-elizkizunak: egoera hauetan betetzen zuten protokoloa ezagutarazten du. Piarres etxeratzen den bakoitzean berriro tradizioei heltzeak agerian uzten du Piarres IIk, Piarres I osatzea duela eginkizun nagusi, heriotzaren inguruan ohikoa den eginbideak, zein etxe baten jarraitutasuna bermatzera datozen urratsak finkatuz, ezkontza-eskariari eta ezteiei dagozkien formalitateak jakinaraziz. Alor honetan senpertarrek daukaten ohiturez aritzea, agidanez, gutxitxo izan eta, Nafarroa Beherean zenbaitetan egiten diren «etxe-sartze» handiak gehitzen ditu (II, 202-203 orr.).

Oihanaldeko etxekoandrea zen Gaxuxaren heriotzak, segida abian jartzea eskatzen zuen: ezkontza-eskari eta ezteien antolatzeko eraz jarduteko parada aproposa. Horiek eta gero iritsiko da etxearen iraupena ziurtatuko duen oinordeko berria.

Azkenean, mataza bat ehotzea baztertuz, Piarres pertsonaia dela medio, XX. mendearen bigarren hamarkadan senpertarrek zeramaten bizimoldea du gai Barbierrek. Bizimolde honek 1914-1918 urteen artean jasan zuen aldaketaz ere arduratzen da. Batzuk, gudu-zelaian nozitu zuten, besteak, Senperen bertan, guztiak erasanaz, jakina, baita Senperen gelditutakoak ere, Barbierrek gogoratzen duenez:

Ortzegun guziez gero, Gerlako Mezara biltzen ziren etxeko doloratuak oro. Etxe bat ez zen, norbeit meza hartara igorriko ez zuenik. Hiru-hogoi, lau-hogoi, ehun komunionetaraino bethi (II, 51 or.).

Etxea gorde mezua igortzea jomuga, zaindu behar dutenaren nolakotasuna bistaratzeko tresna bihurtzen ditu bi liburukiak.

Bai ohiko biziera, bai gerrakoa, adierazteko erakuskari batzuetara jotzen du. Ez batean, ez bestean, dago egunerokotasunik, bereizitako kontu batzuk baino: soroetatik harrak uxatzeko erretoreak egindako zeremonia; ihesari lotu zitzaion Goienbide landetxeko jabeari gertaturikoa; frantsesez ez zekien soldadu garaztarrari jazotakoa; eliz festa desberdinetan ospatzen diren elizkizunak; behin batean kontrabandoan egindakoa... Esaten duenean ez ezik, esateko moduan ere, erakuskariak pilatzen ditu. Adibidez, Piarresi igortzen dioten lehen gutuna bere osotasunean jasotzen da. Hitzez-hitz ematen du kontalariak (II, 35-39 orr.), baita Piarresek idatzitako erantzuna ere (II, 41-43 orr.). Erakuskari bat da. Aurrerantzean ere gutunak ailegatuko zaizkien arren, tankera desberdinez baliatuz agerraraziko ditu herritik bidalitako albisteak.

Erakuskari hauen bidez, indarrean dagoen ordena zehazten du eta hala jarraitzearen alde egiten: betirako izan bedi. Beraz, euskal etxeari dagoen-dagoenean eutsi behar zaio, ordena hori iraultzera datozenen aurka borrokatuz, nahiz hiritarrak izan, edo euskal etxeak kokaleku duen Frantzia etxea inbaditu duten alemanak. 
Berez, Barbierren azken muga ez da Gerra Handiaren kronika egitea, baizik eta euskal etxetzat daukana belaunaldiz belaunaldi berdin-berdin atxiki behar dela irakastea. Helburua betetzeko euskal etxeko bizilagunen balore-sistema eta ohiturak azaldu zituen, baita hauek ezabatzeko asmoz sartu zaizkien hiritar eta alemanei nola aurre egin zieten ere. Bada alderik bi etsai hauen erasoek eragindako hitz-jarioaren neurrietan, izan ere, ez ziren maila berekoak, baina biak salatu zituen eta aurkeztutako euskal etxea kosta ahala kosta babestu beharra azpimarratu.

\section{ETNOLOGIA ETA KRONIKA ETXEA GORDE ALDARRIKATZEKO}

Gerra Handiaren hasieraren mendeurrenarekin batera mende erdia egin zuen Gabriel Arestiren Harri eta Herrik (1964). Arestik ere, "Aitaren etxea defendatuko dut» zioen Harri eta Herrin. Maila ideologikoan elkarrengandik zeharo urrun ibilitakoak bat etorri ziren «aitaren etxea» defendatzean, etxearen harroinen izaera partekatu ez izanagatik.

Aitaren etxea jagoteak darama Piarres gerrara. Abiatu aurretxoan saihesteko aukera bikaina eskaini ziotenean, itxurak gorde barik, uko egin zion. Bat-batean, ordu arte ezezaguna zen pertsonaiak Oihanalde bisitatzen du: Agustin beratarrak. Hona Piarresi luzatzen dion gonbita:

Ez nauzue behar bada, ni ezagutzen. Bainan, nik ezagutzen dut Piarres. (...). Gerla izigarri bat hastera doa. Galbideak oro utzirik, nahi duzu nerekilan ethorri?... Zu bezalako gizon gaztearentzat bada toki gure etxean! Berrehun pezeta zureak dituzketzu, hilabethe guziez (I, 179 or.).

Oihanaldeko sukaldean ziren guztiak asaldatu zituen proposamenari, gisa honetan erantzuten dio Piarresek:

Zertarat ethorria zira gaur, deus nehork galdatu gabe? Ala laido egiten zaioten gizonetarik batentzat daukazu Piarres Oihanaldekoa?... Ez, jauna, ez! Eskualdun lurra ez dut nahi galdu (I, 180 or.).

Agustin beratarrak beraiekin euskal lurrean segituko lukeela argudiatzean, «Ez ordean gurea» (sic) (I, 180 or.) ihardetsiko dio Piarresek. Amnistia bati esker urte batzuetara itzultzea izango lukeela eransten dioenean, Piarresek, berriz,

Hobenduna da amiztiaz behartzen. Amiztiarik gabe nahi ditut (...) ene aita-ama gaixoak lagundu Oihanaldeko eliz-hilherrietarat, eta amiztiarik gabe, egun batez, nahi naiz etzan nihaurek zaindu eliz-hilherri horietan... Anhartean, zuhaurekin eta zuhaurentzat atxikazu zure diru madarikatu guzia. Nere lagunen odolaz gorritua ikus niro bethi. Ez dut nahi! (I, 180 or.).

Piarresen ama Gaxuxaren iritziz, «Eta, zuk, Piarres, jakin zazu hila nahiago zaitugula zure aitak eta zure amak, ezen ez eta bethikotz desohoratua!» (I, 180 or.). 
Gaxuxa ez da horrela pentsatzen duen senpertar bakarra. Senperera aurreneko senpertarraren heriotzaren berria iritsi zenean, kontalariak, lehenbiziko aldiz, gerra-eremua laga eta, Senpereko albisteak helaraziko dizkio Piarresi. Horien artean, senpertar batek Senpereko erretoreari aitortutakoa: «Jaun erretora, hila dela nahiago dut aditu, ezen ez eta mugaz bertzalderat iragana» (II, 49 or.).

Kontalariak argi utzi nahi du senpertarren artean hedatuen dagoen ikuspegia: etxea defendatu. Baita heriotza badakar ere. Eramankorragotzat jotzen dute heriotza, mugaz bestaldera ihes egitea baino.

Bada beste testigantzarik ere, ihesa gaitzetsiz, gerrara joatearen alde egiten duenik. Esaterako, "Aldudeko gerlarien bestan, 1919ko agorrilaren 2an, Etchepare medikuak egin mintzaldia»n adierazitako balorazioak:

Mihian dut Baigorriko herritik duela bortz urte xutitu gazteria ederra. Muga hurran izan gatik, bat etzen gelditu Parisetik jin hel-oihu saminari gor. A! zoin gogotik zoazin oro gudurat! (Charritton, 1992, 233 or.).

Edo,

Baigorriaren kar bera Urepeldarrek, aitzin hartarat helduz geroz. Muga hurbil izan gatik -Baigorrin baino hurbilago oraino- hanitzek nahiago ukan zuten beren odola ixuri, eginbideari uko egin baino (234 or.).

Edo,

Zer esanen dut Bankarrez, (...) Muga hurbil zen bizkitartean hemendik ere, bainan sorterriaren amodioak hetsia zakoten, mendiak baino goragoko zedarri batez. Euskaldun garbi eta frantses egiazko, etzizaizkon joan bertzalderat (235 or.).

«Gerlarien ohoretan» antolatutako hitzaldi batekoak izateak lagunduko zuen baina, hiru leku desberdinetan dio «muga hurbil izan arren» gerrarako deiari men egin ziotela.

Lau urtera, Alduden zen hizlari Etchepare. 1923ko maiatzaren 13an ospatutako «Gerlako oroitmen aldudarrena» ekitaldian lehengo ustea berresten du:

Izendatiak izan diren hameka gizonak, gure artian bizi ziren (...). Buruzagien deiadarra aditu bezain laster, abiatu ziren halere, bertze aldudar andana batekin (...). Erakuspen eder, urrats miragarri, egiazko gizon egintza! Eta orobat bertze nihungo frantsesena baino merezimenduz handiagoa. Alabainan ihes joaiteko, muga ondo ondoan zuten: Frantzian gerla, Espainian bakia; hemen griñarik baizik ez eta, bertzeen meneko, beti lanjerrian; hortxe, mendiez bertzaldian, libertatia, deskantsia, irabazpidia, familiaren, noiztenka bederen, nahiz ixilka, ikusteko zoriona. Bainan ez: ihes egiteko xederik gogorat ere ez zitzaien jin (257 or.).

Etxea, herria eta Frantzia ditu «xixpa» hartzeko motibo Piarresek: 
Eta Piarresek badaki orai zertako den, gaur, xixpa bat eskuan, han, Iguzki-aldeko hiri muthur batean. Frantses-Herriaren mokor bat, mokor ttiki bat zaintzen du harek ere, han, harmetan. Ehun milaka, bertze soldado batzu baziren, non-nahi bertze lurmokor batzu gerizatzen zituztela hala hala. Eta Frantzia, Herri Handia, lur-mokor hetaz guzietaz egina zen. Lur-mokor hetarik bat zen Eskual-Herria, Eskual Herrian Senpereko herria.

Lur-mokor hetan, heien gainean altxatuak, han ziren haren gibelean, aintzinean, ezker, eskuin, orotan, herriak, etxeak, elizak, hil-herriak. Herri hetan, etxe hetan zauden... aita-amak, haurrideak, haurrak, hil gaixoak. Eta, hil eta bizi, hek guziek bakean bizi nahi zuten eta lo egin deskantsuan (II, 11-12 orr.).

Arreba Mariek Piarresi bidalitako lehen gutunean, hitzez-hitz ematen den horretan, arrebak bat egiten du Frantzia menperatu dutenen aurka borrokatzeko Piarresek zituen arrazoiekin:

Jainko horrek berak nahi zuen joan zintezen; Frantzia gerizatu behar zen, eta Frantzia gerizatuz, gerizaturen duzue gutarik bakotxaren herria. Ezen, gure herria zer da, baizen eta xoko bat Frantzian? Eta Herriaren amodioa zer da, baizen eta xoko horrentzat Jainkoak berak gure bihotzean eman duen kilika edo asikia? (II, 37 or.).

Bestela jokatu duena arbuiatzen duela ere gaineratzen dio: «Begi onez ez diozoke beha eginbide horri ukho egin dionari» (II, 37 or.).

Etxea defendatzea Jainkoaren nahia zelako edo, zeregina alboratu duenak zigorra jasoko du. Hala gertatzen zaie Goienbidekoei, Mariek Piarresi igorritako eskutitzak dioenez,

Behazu, Piarres, Goienbidean gerthatu zaiotenari. Mugaz bertz-alderat joan da Batixta, bere ama xaharra, bere andrea, bere hiru haurrak hemen utzirik, geroxago horiekin ororekin uraz-haindirat, Ameriketarat joaiteko. Hamar egun gabe, haur gaixoetarik bat hil izan da; eta haren ehortz-egunean, aita dohakabea ez zen han, bere lagunaren aldean, gorphutz ttikiaren hil-herrietarat segitzeko... Ezkilak dan, dan, dan ari, eta mugarri hurbil, bixkar batean, nigarrez ikusi omen dute aita ihestiarra!...

Eta, orai hiru egun, Goienbideko andre gaixoa bere bi haurrekin joan da, bere aldian, Espainiarat buruz, eta (...) atzo erori da Goienbidea (II, 37-38 orr.).

Piarres «xispa» soinean duela aurkeztu aurretik ere, kontalariak jakinarazia zuen, berak moldatutako pertsonaiek etxea (I, 65, 66 orr.), herria eta Frantzia (I, 29 or.) maite zituztela.

Azken batez, Jainkoa eta etxea ditu ardatz Barbierrek Piarres I eta IIn, Piarres Oihanaldeko oinordekoa ezaugarritzean. Oinordekoaren bizimoldea azaltzeko ohikoaz eta ezohikoaz baliatzen da. Ohikoa da lana, egokitzen denean kontrabandoa egitea, 
aisialdi orduetako pilota eta musa, elizak iragarritako elizkizunetan parte hartzea... Ohikotasun horretara zenbait egintza berezi ailegatuko dira: gerra, amaren heriotza, ezkontza. Horiek dira behin bakarrik jazoko zaizkionak, urtea joan eta urtea etorri errepikatzen den egitarautik aterako dutenak. Ohiko bizimodutik idokitzen dutenean, egoera berriari aurre eginaz, berriro lehenera itzultzea du jomuga. Gerrara etxea defendatzera, gerizatzera doa. Amaren heriotzaren ostean, Goañarekin ezkontzen denean, "xutik berriro etxea» dio kontalariak. Etxearen jarraitutasuna Piarresen ahotsean behin eta berriz entzuteak ere, funtsezko duela agerrarazten du.

Lehen partearen agindupean jorratzen da bigarrena, aurreneko liburukiak ezarritako eskakizunei erantzunez doa bigarrena. Gerrako gorabeherak berrogeita hamar orrialdetara mugatzen omen ditu: horrek berorrek salatzen du Barbierrek ez zuela xede nagusi gerraren kronika egitea. Gerra Handia Ipar Euskal Herriko bizilagunek jasan zuten gertari oso lazgarria izanik, oraindik oso eraginbera zegoen oroitzapen kolektiboan: triskantza hark sorrarazitako oinazea gainditzeko artean gertuegi zeukaten. Oroitzapen kolektiboan barreneraino sartuta zegoen bizipen basatia gogaraziz, euskaldunak etxea gordetzearen premiaz ondo jabetuta zeudela ezagutarazten du. Gerraz kontatutako pasadizoek, etxea jagoteak eskatutako ahaleginak zenbaterainokoak izan ziren helarazteaz bestalde, Jainkoaren nahia bete zela nabarmentzea dute helburu.

\section{ERREALITATE LINGUISTIKOAREN ISLAPENA. ELEBAKARRAK ETXE ELEANITZEAN}

Esan den moduan, XX. mendearen bigarren erdi arteko eleberrigile guztiek, jokabideak arautzeko bitarteko bihurtu zuten eleberria, euskaldunaren portaera eredugarria bistaratzeko leku. Piarres elizaren, etxearen eta hilerriaren gainean bermatzen bada eta Barbierrek Supazter sokoani gehitu zion aitzinsolasean benetako euskalduna elizak, etxeak, hilerriak eta mintzairak egiten dutela badio, Hegora begiratuz, hilerria kendu eta, osterantzekoak berdin-berdin daude indarrean. Hegoan, euskaldunak izan beharko lukeena erakustera bideratu ziren eleberrigileek euskara, euskal ohiturak eta fede katolikoa zituzten zutarri zinezko euskalduna finkatzeko. Hitz batean, gurasoengandik, aurrekoengandik iritsitakoak bere horretan iraun dezala. Aipatu adierazleekiko harremanak jartzen du pertsonaia goresteko ala arbuiatzeko irizpidea.

Euskarari dagokionez, hizkera-mailak bereizten direnean, beti erregistrorik landuena kontalariarena da, hurrengo, pertsonaia nagusiarena. Errealitate linguistikoren bat islatzeko, bigarren mailako pertsonaiaren bati egozten diote eginbidea.

Euskararen errealitate linguistikoaren ezaugarri da euskalki, azpieuskalki eta aldaeretan banaturik bizitzea eta ahoskeran kontrakzioak egitea. Zenbait kontakizunek eremu geografiko errealetan tokitu dituzte kontatutako istorioak eta bada pertsonaiaren jatorri edo kokaguneko hizkeraren lekukotasunen bat jaso duenik. Agirreren Garoan, kasu, Aloña mendian garatzen da istorioa, nahiz eta ilusio erreferentziala sortzeko 
asmorik ez zuen izan, esparru geografiko erreal horretan hitz egiten den euskalkiaren aldaera gipuzkeragatik ordezkatu izanak egiaztatzen duenez. Alabaina, ez zuen etsi gertalekuko hizkera errealaren arrastoren bat laga barik. Zabaletako familia haur jaio berria bataiatzeko Oñatira jaisteaz baliatzen da oñatiarren ahotsera hauen hizkerako formak eramateko: «landare berrixa aldozue? (1981, 73 or.), «gizon gordiña zagoz, (73 or.), «Zer izen ipiñi bihar xaue? (74 or.). Edo, Zabaleta baserriko Joanes artzainaren biloba Martin mitinlari agertzen denean Eibarren, honen aurreko hizkera, ekitaldiaren herrikoarengatik aldatzen $\mathrm{du}^{11}$.

Barbierrek ere eremu geografiko erreala hautatzen du, baita errealitate linguistikoko aztarnen bat uztea ere. Agirreren Garoan bezala, bigarren mailako pertsonaia baten berbetan mamituko da: Piarresen lagunik handiena den soldadu garaztarraren mintzuran Garaziko euskararen zenbait berezitasun txertatuko ditu.

Arestian baieztatu denez, euskararekiko atxikimendu-maila ere pertsonaiaren ebaluazio-irizpide da. Berriro, Agirreren aipamena derrigorrezko. Kresalan badira zenbait pertsonaia «Bedar txarrak» metaforapean batzen dituenak. Arranondoko belar txarrak dira. Batzuk euskararik ez dakitelako, besteren batek euskara mesprezatzen duelako, gaztelania dute komunikazio-tresna, kontalariak kontakizuna euskaldunentzat egin izanagatik, euskaraturik ematea erabakitzen badu ere. Belar txarrak dira ereduzkotzat daukan balore-sistema hausten dutelako eta, preseski, horiek dira Arranondon gaztelaniaren alde egiten dutenak.

Agirre eleberrigileak hainbesteraino du euskara euskaldunak beharko lukeen baloresistemako osagai, non sinesgarritasunik gabeko egoerak aurkeztera iristen den. $A \boldsymbol{u}$ ñemendiko Loreako (1898) Riktrudis frankoen duke zen Adalbaldorekin ezkontzean, Ostrabentora lekualdatzen da; frankoen herrira, alegia. Erbesteratu dela onartzen duen Riktrudis euskaldun eredugarriak euskaraz bizi izaten jarraitu nahi eta, kontalariak dioenez, euskara darabil erbestean:

Riktrudisek, bere atsakabeak (sic) errezago eruateagaitik, eta biotzak alan eskatuten eutsalako, Euskalerri txiki bat egin eban Ostrabenton.«Erbeste» ipiñi eutsan etxeari izena, zerren, lurra gizonentzat erbestea dan legez, erbestea zan Riktrudisentzat prankotarren erria. Baiña guztiz ondo ta Euskaldun bizi zan. Euskeraz itz egiten zan beti Erbesten, euskeraz arren, euskeraz erestu, Euskalerriko ipuiñak esan, euskaldun ekanduakaz bizi, euskaldunen gisara iantzi... (1966, II, 120 or.).

11 «Langilliak: Euskalerrixan jaixo naiz, baña euskaldun izatiak eznau batere arrotzen. (...). Euskalerri guztia, Eibar izan ezik, abadien mendian dago, ta nik eztot iñon mendian egon gura». Villasante, L. (arg.), 1981, 291-292 orr. 
Garoan, gatazka linguistikoa irudikatzea ez zuen alboratu: Zabaletara Gabonak igarotzera etorri zirenean pertsonaia nagusiaren seme gazteena zen Juan Andres eta euskaldunak ez ziren honen emazte galiziarra eta semea, kode linguistikoa partekatzen ez zutenak sukalde berean elkar ezin ulertuz ${ }^{12}$ kokatu zituen.

Gaztelaniaz mintzatzen diren Euskal Herriko pertsonaiak hobesten duen balore-sistematik aldentzen diren pertsonaia legez ezaugarritzen baditu Agirrek Hegoan, Iparrean jarrera berbera atzeman daiteke, Barbierren aurretik ez ezik, baita ostean ere. Egia da Daskonagerrek frantsesez idatzi zuela Les échos $d u$ Pas de Roland eta besteek euskaratutakoa dela, egilea gain-gainean zutela, ordea. Horregatik, egileari berari egotzi dakioke euskaraz Atheka gaitzeko oihartzunak izenburupean argitaratutako kontakizunean, Ganixen aurka dabiltzanentzat eta arrotz zaizkionentzat frantsesa gorde izanaren erantzukizuna.

Piarres IIren ondotik, Anttonen, Marixan Anttonen usteetatik urrutiratzen denean, Anttonen balore-sistema urratzen duenean, haren ahotsera frantses gaiztoa darama Iratchetek. Euskara frantsesarengatik ordezteaz bestalde, zuzen beretu ez duen hiztun moduan nortzen du.

Piarres IIn ez zuen berdin jokatu Barbierrek ${ }^{13}$. Taxutu zituen pertsonaiek euskaraz baino ez dute egiten, gerrara joan behar dutenei hizkuntza-testuingurua aldatzen zaien arte. Ingurumari linguistiko berrian, pertsonaiak baliatu hizkuntzari eutsi zion. Agintari militarrentzat soilik frantsesa (besteak beste, II, 177-178 orr.), soldadu euskaldunentzat frantsesa zeharo baztertu barik (besteak beste, II, 59, 66, 188 orr.), gehienbat euskara eta, azkenik, frantsesaren arrastorik ez zuen soldadu euskaldunik ere bazela ezagutarazi zuen (II, 83 or.). Barbierrek hizkuntza-errealitatea islatzen du, errealitate horren alderdiren batek eragin zitzakeen arriskuak aztertzea saihestuz. Agerikoa denez, frantsesik ez zekien soldadu euskalduna baldintza zailetan zegoen: agintari militarrek frantses hutsa darabilte eta agintari horietakoren batek behintzat etxe bereko duten hizkuntzari ez dio ongi etorririk adeitsuena ematen: «Hé, là! qu'est-ce que vous

12 «Iñondik iñora ezin ulertu zuten alkar Ana Josepak eta bere Galiziko errañak.

-Baneukan zuek ezagutzeko gogoa- esaten zion arrek.

-No le entiendo a V. una palabra -erantzuten zuan besteak.

-Esne sopak jango alditu mutillak? Urdai azpikoa jarriko aldizuet?

-Lo mismo que si me hablara V. gringo. Jesús qué lenguaje!

-Etzaite aserratu, emakumea.

-¿Qué dice tu madre, Juan?", 190 or.

13 Eginiko baieztapena berretsiz, azalpen bat. Labur samarra den Iratcheten Antton kontakizuneko Anttoni hainbat pasadizo bizitzea suertatzen zaio: etxea erre, indiano bihurtu, II. Mundu Gerran (1939-1945) alemanei aurre egitea... baina, kontalariaren berbaldian lekurik handiena hartzen duena Antton eta Marixanen arteko harremana da eta, honen barnean, Marixanek hirian izan duen eraldaketa. Piarres I eta IIk etxea jagotea badute gune, Anttonek hiriak dakartzan galerak. Geroago Iratchetek jasoko duen ikuskera, bi liburukiok jendarteratu baino lehen, jada adierazita zeukan Barbierrek, Supazter sokoan idazlanarentzat moldatutako hitzaurreak erakusten duenez: «bereziki neskatxa batzu, urthe pare bat edo gehiago hirian egonik, herrirat ethorri eta, frantsesez -beren ustez- hasten zauzkularik! Zer frantsesa, heiena! Ez frantses, ez kaskoin, ez portuges! Nik ez dakit nongo mintza-moldea duten hura... Ez bethi Frantziakoa!», 39 or. Piarres I eta IIn, haatik, besterik zuen ardatz. 
dites dans votre diable de basque?»(II, 72 or.). Antzeko zerbait zioen Garoako Juan Andresen emazte galiziarrak: "-Lo mismo que si me hablara V. gringo. Jesús qué lenguaje!».

Esan beharrik ere ez: batak bestearen hizkuntza ezezaguna izateak sorraraz ditzakeen arazoak ez dira parekoak baserriko sukaldean eta gudu-zelaian. Sukaldeko solaskideek itzultzailea izateaz gainera -Zabaletako seme Juan Andres moldatzen da gaztelaniarekin- ahaidetasunak lotzen ditu. Oso bestelakoa da gudu-zelaiko agintari militar soldadu harremana. E. Bidegainek ohartarazi duenez, «euskaldun anitz frantsesa ez jakiteagatik hil ziren, aginduak ez zituztelako ulertzen» (2008). Barbierren kronikan frantsesik ez zekien soldadu bakarra aipatu eta, gabezia hori bistaratzean, gatazka ekiditen da. Izen bereziarekin izendatzen ez den garaztar batek egin balentriaren ondoren, komandanteak deitu eta, galdetu zion:

\section{D'où êtes-vous, mon brave?}

\section{Bustintziarrak frantses tuntik ez jakin! (II, 83 or.).}

Barbierrek bideratutako irtenbidea eztitzat eta, aldi berean, lazgarritzat jo daiteke, nahiz eta, euskaldunak noraino barneratu zuen gerra azpimarratzeko lagungarri izan. Oztopoa agerraraztean, itzultzaile-lanaz arduratuko den pertsonaia hantxe bertan:

Eskualdun aphez-gai bat gomenantarenganat mezulari hain xuxen orduan suertaturik, haren medioz jakin zituen aintzindariak berriak oro, eta uste ez zituenak ere bai. (...). Eta bost haurren aita zen, nehor ez zela gauza horri ohartu, eta berak ere deusik ez zakiela hura altxatuz geroztik eginikako legeez! (II, 84 or.).

Garaztarraren zirkunstantzia pertsonalak helaraztean, komandantearen zintzotasuna, erabatekoa:

\footnotetext{
Ta place n'est pas ici, mon garçon... Des soldats comme toi, j'en voudrais beaucoup. Mais un père de cinq enfants n'a pas le droit de se faire casser la figure... Pour l'instant, je vais te faire évacuer à l'arrière, et nous verrons ensuite à régler ton dossier. J'aurai du reste à le grossir de quelques lignes bien méritées (II, 84 or.).
}

Ustekabeko gertaera bat tarteko, tupustean, berebiziko oparia garaztarrarentzat, kode linguistikoa partekatzen ez dutenak elkarren berri izateko apaizgai elebidunaz gain, legea betetzeko prest dagoen komandantea eta, horrela, eztietan eztiena den emaitza: etxera itzuli. Baina, ez ote gogorra etxean behar zuena, ezjakinean, gudu-eremura eroan izana? Nola ezagutuko zituen beretu gabeko hizkuntza batean idatzitako legeak? Nori zegokion jakinaraztea? Nola ulertuko zituen agintari militarren aginduak? Garaztarrak etxeratzea pozik hartu zuela gaineratze hutsarekin amaitzen du Barbierrek pasadizoaren kontakizuna. Iruzkin eta gogoeta franko egiten dituenak elebakartasunak sortutako traba arakatzea baztertzen du: ez dago arazorik, elebakartasuna ez da gatazka-eragile. Euskaldun elebakarrak euskararik ez zekitenen esanetara egon zirenaren testigantza baino ez. Kontakizunera ekarritako erakuskariaren arabera, komunikazio-eragozpenak 
gaindi daitezke eta, bidenabar, euskaldunen adorea eta agintari militar frantsesen prestutasuna nabarmentzeko balio izan dio.

Esan bezala, bi aldetakoek, Ipar eta Hegokoek, balore-sistema berbera hobetsi dute Barbierren aurretik, zein ostean. Bidegainek «Euskaldunak frantsestu zituen gerla»tzat $(2008)^{14}$ jo du Gerra Handia. Hemen behatutakoaren arabera, Lehen Mundu Gerraren hasiera urrun zela -Atheka gaitzeko oihartzunak (1870)- eta bukaeratik mende laurden luzea eta gero -Antton (1946)- frantsesa ez dute atzematen Barbierrek Piarres IIn aurkeztu bezain etxeko ${ }^{15}$.

Erdaraz baliatzen diren pertsonaiak arroztutakotzat dauzkate Daskonagerrek, Agirrek edo Iratchetek. Komunikazio-hizkuntza gaztelania duten «Bedar txarrak» arrotzak dira Kresalako arranondotarrentzat, baita Garoako Zabaletako seme Juan Andresen emazte Dionisia eta horien seme Juanito ere, ahaide euskaldunentzat. Orobat, Atheka gaitzeko oihartzunak kontakizuneko Ganixentzat frantsesa darabiltenak eta hizkuntzaz aldatzen duen Anttoneko Marixan Anttonentzat. Aitzitik, frantsesez soilik mintzatzen diren agintari militarrak ez zaizkio arrotzak Barbierri ${ }^{16}$.

Agintari militar horiek ezin izan zitezkeen arrotzak Barbierrentzat, eusten ari diren etxeko bizilagunek hizkuntza desberdinak hitz egiten dituztelako. Garoako Juan Andres jaioterritik Gaztelara bideratzean, atzerriratu izana leporatzen dio kontalariak. Auñemendiko Loreako Riktrudisentzat frankoen herria erbestea bazen ere, ez Senpereko Piarresentzat Frantzia. Senpertarrek alemaniarren aurka borrokatzeko gudu-zelaia bizitoki dutenean, ez daude atzerrian, beren etxea gerizatzen baizik. Kontalariak jakinarazia zuen, «Eta Frantzia, Herri Handia, lur-mokor hetaz guzietaz egina zen. Lurmokor hetarik bat zen Eskual-Herria, Eskual Herrian Senpereko herria» (II, 11 or.).

Horiek horrela, argi uzten du Barbierrek batak bestearen hizkuntza ezagutzen ez duten etxeko bizilagun direla. Elebakardunek ere eleanitza den etxea dute bizileku.

14 Bidegainek «Eskualduna astekariak Mundu Gerraz zabaldu zuen mezua» ikertzen du Lehen Mundu Gerra "Eskualduna» astekarian (2013) azterlanean. Hitzaurrean bertan dio, "Eragin handia izan zuen ere euskaldunak frantsesteko bidean", 26 or.

15 Iratcheten Anttonen frantsesa ez Piarres IIn bezain etxeko, bai horratik, Frantzia babestea. Etxea erretzen zaienean galerei aurre egiten Amerikak lagun diezaieketela eta, bertaratzea eskatzen dio aitak Anttoni. 1937ko urriaren hogeian sartu zen ugazaba amerikarraren etxean. Irabazi onak ditu, amak 1939ko ekainean idatzitako eskutitzean jakinarazitakoagatik, aurreikusitako egonaldia aurreratu behar duen arte: «etxerat jin behar duk. (...). Ene pentsatzeko moldean, ixtant bat goiti beheti, gerla segurra duk». Urkizu, P. (arg.), 1990, 40 or. Bigarren Mundu Gerra hastear da eta, amarentzat, «Eta ez bahiz jiten, desertor hiz. Nik ondarrekoa egina diat eta ez diat ene familiat desertorrik ikhusi nahi», 40 or. Barbierrek hobesten dituen pertsonaiek Lehen Mundu Gerraren egunetan aditzera emandako ikuspegi bera azaleratzen du Iratchetek Bigarrenean.

16 Piarres I eta II baino lehen plazaratu zuen Supazter sokoanen, benetako euskaldunaren harroinak elizan, etxean, hilerrian eta mintzairan jarri zituen Barbierrek. Alabaina, jarraian honakoa erantsi zuen: «Begira... Elizan, Etxean, Hil-Herrietan hartu guzia: sinheste, errespetu, Jainkoaren beldur eta amodio. Horietarik deusik ez erain sekulan arrotzaren aintzinean eta haren beldurrez», 30 or. Nahiz eta puntu eta apartearen ostean, «Bainan, begira oroz gainetik gure mintzaira, Eskuara» gaineratu, arrotzaren aitzinean gorde behar direnetatik at lagatzen du. 


\section{JAINKOAREN NAHIAK GOBERNATUTAKO ETXEA}

Aipatu denez, apaizek taxututako kontakizunetan bada fedeak eragindako berbaldirik, baina Barbierren neurrietara iritsi barik, bai oparotasunaren ikuspuntutik, bai gizakiaren menpekotasuna azken muturreraino eramatearen alderditik ere: gizakia Jainkoaren erabakien esku dagoen izakia da.

Jainko zale dira Piarres pertsonaia nagusia eta, eskuarki, euskaldun guztiak: «Jainkoa! Bethi Jainkoa! Orotan ere den bezala, orotan ikusten zuen eta maitatzen gure Piarresek (...). Eskualdunak odolean du hoi, eta Piarres zinez eskualduna zen» (I, 116 or.). Era berean, «Eskual-Herriaren bihotza beraz... eliza» (I, 128 or.) erantsi eta, euskaldun guztiak zeruan kokatzen ditu: «ezen, euskaldunik ez diteke zeruan baizik» (I, 128 or.). Euskaldun izaeraren bereizgarri da, ez kontakizunaren orainaldian bakarrik, betidanik baino: «eta eskerrak bihurtu ziozkaten biek... eskualdun Etxeak bethitik begiratzen dituen Jainko handiari» (II, 216 or.). Hala izanik, Piarresen eta, oro har, euskaldunen kristau-fedearekiko atxikimendua erakusten duten lekukotasunak ugariak dira. Lekukotasun horiei kontalariak emendatutako iruzkin anitzak batzen zaizkie. Gisa honetan, euskaldunak kristau-fedearekin duen lotura zenbaterainokoa den irudikatzeaz bestalde, fede hori nola ulertzen duen ere agerrarazten du. Ez zebilen oker Etchepare honakoa egotzi zionean:

Baditake hanitzek beltzuri eginen dakoten oraino Barbieri, hil ondoaz bai eta elizako zerez arduregi eta nasaikiegi delakotz heien iduripenerat mintzatu. Aitortuko dut apez euskaldun gehienen itzala dela hori, luma, populuaren argitzea gatik, erien artean dutenean hartzen: akitu ondoan irakurle gaizoa, kexarazten dauzute eta batzutan higuintzen. Ohartzeko lukete, erligioneaz, han-hemenka eta laburzki baizik ez dela behar liburu batean, nola astekari edo egunkarietan, hitz egin: halako hitzak, guziz indarrekin delarik igorria, gibelondo hobea baiterakar buru bihotzetan, elasturiak baino (Charritton, 1984, 362-363. orr.).

Hutsik egiten ez duten bi erakundeak Eliza eta Eskualduna aldizkaria dira. Horra, kristau euskalduna gobernatzeko aginpidea dutenak:

Piarresek bazakien zer egin bozkatze heieri buruz. Eskualdun astekariak errana zion nor ziren heien aintzinerat agertzen ziren bi gizonak, eta gizon hetarik zein behar zuen hautatu eskualdun girixtinoak (I, 140 or.).

Norbere burua eraentzeko bi iturri baino ez, banaketa jakinarekin: bizitza zibila eta erlijiosoa.

Euskaldunak, azken batez, bi etxe ditu, bata aldi baterakoa, bestea, berriz, betikorakoa. Etxeak aterpea, babeslekua, segurtasuna sinbolizatzen du (Pérez-Rioja, 1980, 115 or.). Denboraldi baterako, horratik. Babesleku horri segida emanaz, beste etxera igarotzea lortu behar da. Euskal etxeko bizilagunek izan duten eta duten balore-sistema gordetzeak sarrera bermatuko die.

Beste etxea eliza da. Hau joandakoen eta bizi direnen topaleku da: 
Herriaren arima herritarren arimek egiten dutela baitiote, Eskual-Herriaren arima han dabil hegaldaka, gure eliza zaharretan, eskualdun egiazko guzien arimak harat bethi biltzen ohi direnaz geroz. Zerua eta lurra, Jainko handia eta gizon ez-deusa, aingeruak eta sainduak, hilak eta biziak, han elgarretaratzen dire, etxe batean etxe hartako burhasoak eta haurrak oro bezala (I, 128 or.).

Amaidun den bizitzan ere, guztia Jainkoaren esku dago Piarresentzat; uneoro Haren borondatea betetzen denaz ziurtasun osoa dauka. Behin, aurrerago emazte izango duen Goañaren «othoitzak eta medaila baliatu zaizkit jada, obuza puska edo bala ttiki batek zakuaren gainetik ene zapatak ereman dazkidatalarik! (II, 41 or.) dio; hurrengoan, sua eta kea bazter guztiei zeriela, «Jinkuak eta Ama-Birjinak beira gitzaztela! Bestenaz!» (II, 144 or.) eskatuko du. «Jainkoak oro zeramazkala orhoiturik, eta haren nahia ez balinbazen, ile bat ez zitzaiola eroriko gogoan harturik, ikare ilhun itsusirik ez zuen bere baitan sumatzen» (II, 44 or.) bete-betean sinesten du. Eta, obus bat ondo-ondotik sartu eta, hogeita hamabost gizonetatik hamabi harrapatzean, lasterka zihoala, «Eskerrak zor izanen ditiagu berriz ere Jainkoari! Hori zerbeit bazian hatik! (II, 61 or.) oihukatu zuen. Edo, hildako senpertar batzuen izenak izendatu eta gogoratu ostean, «Hots, muthikoak, gaineko Nausiak hola nahi zian engoitik!» (II, 80 or.) gehituko du. Gerran zein ohiko bizieran gizakiaren ibilera Jainkoak ezartzen du. Baita ohiko bizimoduan ere, erretoreak soroetako harrak uxatzeko egindako zeremoniaren eraginkortasunak frogatzen duenez: «Jaun erretora, jaun erretora, badoazi; behazu hunat...» (II, 107 or.) adieraziko du Piarresen arreba Mariek.

Barbier etnologoak bere kontakizuna jendeztatzen duten pertsonaietara sorgina ere ekartzen du. Sorgin kristaua, noski. Dena den, badaezpada, Barbier apaiza sineskeria ororen arriskua saihesteaz ere arduratzen da.

Piarres Iean aurkeztua zuen Maria Zaharrak elurrak zoko guztiak zurituta zeuzkan gau batean jo zuen Oihanaldeko atea. Beranduegi ez ote den etxera itzultzeko gaineratzen diotenean, Maria Zaharraren ihardespena,

Zer munta du, eta noren beldur behar naiz? Sorginen?... Bakharrak baitut ikusirik nere bizian aireko horietarik, intha guzietan, eta bethi gauaz!... Ez dute nere gainean ahalik! Sorgina ez naiza nihaur? (I, 86 or.).

Gaxuxaren heriotza dela eta, dator berriro Oihanaldera. Hona bere otoitza Gaxuxaren gorpu aurrean:

Jainko onak bere lorian harturen zaitu, (...). Lehenagoko euskaldunek hola egiten ohi zutela, ongi nahiko zuen xirio xorta bat ixuri Oihanaldeko andre maitearen gorphutzaren gainera, gorphutz hura gogor geldi zadien eta oso kaxaren barnean... Bainan ez zen hartarat atrebitu; eta, ongi othoitz eginik, atheratu zen, galdeginez hatik «hautara bat ile-orratz eman zezaten kaxaren barnean... Bazakiela harek zertako...» (II, 160 or.).

Barbierrek, jakina, ez du ahantziko ile-orratzarekin gertatutakoa ezagutaraztea: "Arratsean, bere soineko ederrenekin kaxan eman zen hil maitea, eta ile-orratzik gabe batere» (II, 161 or.). 
Argi eta garbi, aztikeria guztiak deuseztatu gura dituen Barbier elizgizona gailentzen zaio etnologoari. Elizaren errituek helburua eskuratzeko duten ahalmena bistaratzeaz bestalde, beste jatorri batekoak ezabatzea gomendatzen du, zeren eta gizakia Jainkoak gobernatzen du.

Gizakiaren gaineko erabateko aginpidea Jainkoak baldin badu, ez da makala aginte horren oniritzia izatea. Kontakizun den gerran Jainkoa Frantziarekin dago:

O Jainkoa, Jainko zaintzalea, / Frantses Herriaren kontsolatzalea, / Hel! hel! gure gerizatzalea. / Hel, hel othoi, etsaien xehatzalea!

Alemana, JAINKO ZAHARRAREKIN / Pozoin traidore guziekin; / Jin dadila... nahi duenarekin! / Zer zauku?... Jauna da gurekin! (II, 52 or.).

Piarresen arreba Marierentzat ere, Jainkoak nahi zuen Frantziaren alde borrokatzera joan zedin.

Jainkoa Frantziarekin bada, Haren gogoa da gorde dezatela. Horregatik edo, gerra ekiditeko muga igarotzen duena berehala zigortzen da, Goienbideko nagusiaren ihesaren eskarmentutik ikas daitekeenez: ordudanik zoritxarra lagun, ezbeharra ezbeharraren atzetik.

Seguruenik benetako gertari batez dihardu, besteak beste, izen bereziaren jabe egin dituelako. Nolanahi ere, egiazko ala asmazioaren fruitu izateak ez du aldatzen xedatu zaion eginkizuna: Jainkoaren borondatea da euskaldun soldaduek Frantziarekin konprometitzea gaztigua indartu. Frantzia gerizatzean, beren etxea, bizileku duten etxea bera, babesten ari dira.

Fikzioaren denboraren iraupena laburra izanik ere, zeinahi eleberrigile behartuta dago berbaldira eroango dituen kontuak aukeratzera. Leku egin ala baztertu ariketarekin hasitako baheketari, bereizitakoa moldatzeko era batzen zaio. Burubide erabakigarriak mezuak geruzatzen dituztelako: nabarmentzen denetik osagarrizko betelan mailakora. Barbierri dagokionez, zeharo tolesgabeki bete zuen zeregina; izan ere, aski da begiratzea nola ahots desberdinak baliatuz iritzi berbera azaltzen duen edo adiera partekatzen duten gertaerak kontatzen dituen, beheragoko mailan kokatutakoak errepikatzen ez dituenean. Iragarritako bi baliabideak erabiltzen ditu iteratzeko mugaz bestalderako ihesaren gaian eta, horietakoren bat beste batzuetan, dela hiritarren portaera okerra pasadizo batean baino gehiagotan jasotzen duenean, dela euskaldun soldaduak gerrara joatea Jainkoaren nahia izan zela kontalariaren, Piarresen, Marieren... mintzuretan, frantsesik ez zekien soldadu bakarrari behingo batean jazotakoa jakinarazi eta kito egin zuenean. Azkenean, irakurleari irakurketa ezartzen dio, kontakizuna itxuratzean, nola hartu ere finkatu izanagatik: irakurketa bakarrekoa den testua gauzatzen du.

Hegotik eta, ia mende erdi geroago izan arren, bada oso bestelako ikuskerarik eta, ondorioz, besterik azpimarratzen duenik. Gorka Knörr abeslariak «Azken agurraren 
negarra» (1975) abestiko ahapaldi bakoitzaren ondotik kantatzeko ondutako leloa lekuko: «Morts pour la Patrie, / morts pour la Patrie, / eskuara baizik etzakiten haiek, / morts pour la Patrie».

Barbierrentzat, ordea, Jainkoaren nahiari erantzun zioten eta uste hori duenarentzat, Jainkoarekiko esanekotasunera makurtu eta Haren aginduak onartzea baizik ez dauka gizakiak.

Eliza katolikoak Jainkoari jarri dizkion ezaugarrietan orojakiletasuna, noranahikotasuna, ahalguztiduntasuna, ontasuna, errukitasuna eta abar aurki daitezke. Nolakotasun hauen artean elkarrekin uztartzen zailenak ahalguztiduntasuna eta errukitasuna izan daitezke, batak bihozgabetasunera eta, besteak, bihozberatasunera igortzen duten aldetik.

Behin edo behin Jainko errukigarria, penitentziagileaz urrikaltzen den Jainkoa agerrarazten du:

Jaun erretorak hala galdeturik, herri guziak barur egin zuen ortzirale batez, eta kurutzearen-bide bat egin zen (...). Egun hartan berean, gerlako azken gudueri buruz, eritasun tzarrari buruz, Ama Birjinaren iduri eder batentzat behar zen diru guzia nasaiki bildu zen. (...). Eta -ez zenez miraikulua- arrats hartan berean gelditu zen izurrite ikaragarria, senpertar bihi bat ez baitzen gripatik joan orduz-geroztik, auzo herrietan oraino nigarrez ari zirelarik... (II, 180-181 orr.).

Alabaina, zalantzarik gabe, Jainko ahalguztiduna nagusitzen da. Inolako autonomiarik ez duen izakia da gizakia, Jainko guztiahaldunak gobernatzen duen txotxongiloa: den bezala ahalguztiduna izanik bere esku dago gizaki bakoitzaren bizitzaren norabidea: obusak edo tiroak nor jo eta nor libratu erabakitzen duen, sariak eta zigorrak banatzen dituen Izaki Gorena. Nahiz eta erabakion eustazpiak ezezagun izan gizakiak, ezbeharra, zoritxarra, hobesten den balore-sistema urratu duenen batek jasaten badu, Jainkoak xedatutako zigorrari egozten zaio. Piarres, Jainkoak hala nahita, onik atera eta, bere xedea lortu zuen, Oihanalde etxeari segida ematea, hain justu. Haatik, Barbierrek ez du argitzen zergatik Jainkoaren borondateak bestela jokatu zuen beste askorekin.

\section{ONDORIO GISA}

Mende erdi luzean, euskal eleberria argitaratzen hasten den XIX. mendearen hondarretik XX.aren lehen erdia gainditu arte, ez da kontatu istorio bakar bat ere, ikasbide gabekorik. Denek izan dute jomuga euskaldunaren portaera arautzea. Portaera-arautze jardunean etxearekiko lotura bihurtzen du gune Barbierrek. Etxea gorde. Horra hor, bi liburukien arteko lokarria. Arrotzaren inbasioetatik landetxea gerizatu, dela jauregi ederrarengatik ordezkatu nahi duen hiritarretik, dela alemaniarrengandik. Kanpotarra saihestuz, aurrekoek helarazitako baloreak bere horretan iraungo dute. Etxea oinarrien gain eraikitzen da: seme-alabek gurasoek utzitako ondarea dute euskarri: sinesmen, 
ohitura, balore... Jasotako ondarea babestea eta hurrengoei transmititzea da belaunaldi bakoitzaren erantzukizuna. Urtearen egutegiak dakartzan zereginak lehenagokoek erakutsi moduan burutu, bizitzako iraganbideak gurasoak igaro bezala iragan (ezkontza, heriotza...), ezagututakoa berdin mantentzeko. Horregatik etxea inbaditu duten atzerritarrak jaurti behar dituzte, hauek indarrean dagoena baliogabetuko dutelako. Etxearen jarraitutasuna hautsiko dute. Heriotzak hauts bihurtu dituenen eta hauen ondorengoen arteko segida etengo dute, ez bakarrik beste arbaso batzuk izateagatik, baita beste sinesmen, ohitura, baloreen arabera bizitzeagatik ere.

Etxea eraikuntza bat da. Eraikuntza horretan bizi da familia. Odolekoa den familia eta politikoa dena. Bi familiak zaintzea dagokie, familia politikoaren hizkuntza ezezaguna izatearen gainetik, nahiz eta familiarteko guztiek komunikazio-tresna ez partekatzeak ondorio garratzak eragin, gudu-zelaiko hizkuntza ez dakiten kideen heriotzaarriskua emendatzean. Bata bestearen kode linguistikoa deskodetzeko gauza ez izan arren, ez dira kanpotar. Familia politikoarekin bat egitea komunikazio-tresna berdina daukatenen artean babesteari lehenesten zaio. Ez soilik lehenetsi, baizik eta, bestela jokatzen duena, gaitzetsi.

Azken batez, indarrean dagoen ordenaren iraupena aldarrikatzen da. Gobernatzen dituen ordenan aldaketaren bat sorraraz dezakeenari aurre egiten zaio: erosiz edo indarkeria erabiliz, etxeaz jabetzera datorrenari. Etxean agintari gorenena Jainkoa da, Honen eskuetan baitago banakoaren etorkizuna: Jainkoaren nahia betetzen da nonahi eta noiznahi beti.

Corpus etnologikoak hobesten den bizimodu eta balore-sistema agertzen du. Etnologiari kronika gehitzen zaio, corpus etnologikoan azaldutakoa eusteko familia politikoarekin batera egindakoa aditzera emateko. Berez, kronika deitutakoa Gerra Handiko pasadizo batzuk kontatzera mugatzen bada ere, eskuratu duten ondarearekiko duten atxikimendua erakusteko bitarteko da. Kronikak, arrotza etxetik botatzeak eskatutako ahaleginaren berri gaingiroki azaltzen du, baina kostu handiak izan zituela jakinaraziz. Ahalegin hori corpus etnologikoan bildutakoaren iraupena bermatzeko izan zen.

\section{ERREFERENTZIAK}

Agirre, D. (1898). Auñemendiko Lorea. Bilbo: Euskalzalen moldagintza. Erabilitako edizioa: 1966. Auñemendi-ko Lorea / La Flor del Pirineo. II. Donostia: Auñamendi, 2. argitalpena.

Agirre, D. (1906). Kresala. Durango: Florentino Elosu.

Agirre, D. (1912). Garoa. Durango: Florentino Elosu. Erabilitako edizioa: Villasante, L. (arg.), 1981. Garoa. Oñati: Arantzazuko Frantziskotar Argitaldaria, 5. argitalpena.

Aguiar e Silva, V. M. de. (1975). Teoría de la literatura. Madrid: Editorial Gredos.

Apestéguy, L. (1926). Piarres roman Euskarien par Jean Barbier. Gure Herria, 609-613 orr. 
Aresti, G. (1964). Harri eta Herri. Zarautz: Itxaropena.

Azkue, R. M. (1918). Ardi galdua. Bilbo: Jesusen Biotzaren elaztegia.

Barbier, J. (1924). Supazter sokoan. Baiona: A. Foltzer. Erabilitako edizioa: Valencia Tirapu, E. (arg.), 1987. Supazter sokoan. Zarautz: Itxaropena.

Barbier, J. (1926). Piarres I. Baiona: S. Sordes. Erabilitako edizioa: Sanchez, R. (arg.), 1992. Piarres I, Bilbo: Ibaizabal.

Barbier, J. (1929). Piarres II. Baiona: S. Sordes. Erabilitako edizioa: Loidi, A. (arg.), 1996. Piarres II, Donostia: Mensajero.

Bidegain, E. (2008). Euskaldunak frantsestu zituen gerla. Berria. Azaroaren 11a.

Bidegain, E. (2013). Lehen Mundu Gerra «Eskualduna» astekarian. Bilbo: Euskaltzaindia.

Charritton, P. (1984). Jean Etchepare mirikuaren (1877-1935) idazlanak. I Euskal Gaiak. Donostia: Elkar.

Charritton, P. (1992). Jean Etchepare mirikuaren idazlanak. IV Kazetaritza (B). (19161935). Donostia: Elkar.

Daskonagerre, J. B. (1870). Atheka-gaitzeko oihartzunak. Baiona: Vve Lamaignère.

Eizagirre'tar, J. (1948). Ekaitzpean. Ipuin berri. Buenos Aires: Editorial Ekin.

Etchepare, J. (1929). Beribilez. Gure Herria, 5-6, 425-438, 531-544 orr. Erabilitako edizioa: Kerejeta, M. J. (arg.), 1987. Beribilez, Zarautz: Itxaropena.

Etxeita, J. M. (1909). Josecho. Durango: Florentino Elosu.

Etxeita, J. M. (1910). Jaioterri Maitia. Erabilitako edizioa: Sarriugarte, I. (arg.), 1988. Bilbo: Labayru Ikastegia, Caja de Ahorros Vizcaína.

Iratchet, J. P. (1946). Antton. Herria. Erabilitako edizioa: Urkizu, P. (arg.), 1990. Antton, Donostia: Etor.

Irazusta'tar, J. A. (1950). Bizia garratza da... Buenos Aires: Editorial Ekin.

Iser, W. (1989). La estructura apelativa de los textos. Warning, R. (arg.), Estética de la Recepción (133-148 orr.). Madrid: Visor.

Knörr, G. (1975). «Azken agurraren negarra». Nik Nahi Dudana diskoa.

Lafitte, P. (1933). Parmi les compositeurs de cantiques basques: M. le chanoine Gratien Adéma (1828-1907), M. L'abbé Jean Barbier (1875-1931): conférence donnée au grand Séminaire de Bayonne le 2 Mars 1933 sous la présidence de monseigneur Lasserre. Bayonne: Imprimerie de la Presse.

Lhande, P. (1919). Chronique de littérature basque. RIEV, 10, 190-200 orr.

Mendi-Lauta. (1937). Loretxo. Eguna, II-14, II-18, II-21, II-27, III-3, III-6, III-7, III-11, III-16, III-20, III-21.

Meregalli, F. (1989). La literatura desde el punto de vista del receptor. Amsterdam: Editions Rodopi.

Mogel, J. A. (1881). El doctor Peru Abarca, catedrático de la lengua bascongada en la universidad de Basarte ó Diálogos entre un rústico solitario bascongado y un barbero callejero llamado Maisu Juan. Durango: Julian de Elizalde.

Pérez-Rioja, J. A. (1980). Diccionario de símbolos y mitos. Madrid: Editorial Tecnos.

Robert, M. (1973). Novela de los orígenes y orígenes de la novela. Madrid: Taurus Ediciones. 